\title{
REFLEXIONES ACERCA DE LA ACCIÓN DECLARATIVA DE INCONSTITUCIONALIDAD EN EL ÁMBITO JURÍDICO ARGENTINO
}

\author{
VÍCTOR BAZÁN
}

Universidad Católica de Cuyo, San Juan (Argentina) 


\section{SUMARIO}

I. INTROdUCCIÓN. II. UN ITINERARIO POR LA JURISPRUdenCIA DE LA CORTE SUPREMa de Justicia de la Nación. III. Síntesis de la doctrina de los fallos relaCIONADOS. IV. UN RECORRIDO COMPARATIVO POR EL DERECHO PÚBLICO PROVINCIAL y el de la Ciudad Autónoma de Buenos Aires. V. Epílogo. 


\title{
REFLEXIONES ACERCA DE LA ACCIÓN DECLARATIVA DE INCONSTITUCIONALIDAD EN EL ÁMBITO JURÍDICO ARGENTINO
}

\author{
POR \\ VÍCTOR BAZÁN* \\ Universidad Católica de Cuyo, San Juan (Argentina)
}

\section{INTRODUCCIÓN}

En el presente trabajo analizaremos las vicisitudes vivenciales de la acción declarativa de inconstitucionalidad vis-à-vis las acciones meramente declarativas; la metamorfosis que ha sufrido la primera de las nombradas en la percepción de la jurisprudencia de la Corte Suprema de Justicia de la Nación [en adelante: Corte o C.S.J.N.]; su encorsetamiento en las pautas del art. 322 del Código Procesal Civil y Comercial de la Nación [en lo sucesivo: C.P.C.C.N.]; y su utilidad y valor como herramienta funcional dentro del sistema de control de constitucionalidad.

* Profesor Titular (Catedrático) de las asignaturas Derecho Constitucional y Derecho Internacional Público y Comunitario de la Facultad de Derecho y Ciencias Sociales de la Universidad Católica de Cuyo, San Juan, República Argentina. Investigador y Profesor de Postgrado de dicha Universidad. Miembro Titular e integrante del Comité Ejecutivo de la Asociación Argentina de Derecho Constitucional. Miembro Titular de las Asociaciones Argentinas de Derecho Procesal y de Derecho Internacional, ocupando en esta última el cargo de Secretario de la Sección de Derecho Internacional de los Derechos Humanos. 
Por supuesto, y previo a dar paso a las consideraciones finales, no evadiremos un análisis de las distintas previsiones constitucionales de las provincias argentinas en torno del particular.

En tanto útil para el despliegue de nuestro estudio, y por razones metodológicas, transcribiremos a continuación el mencionado art. 322 del C.P.C.C.N., en su párrafo $10^{\circ}$ Tal tramo de la norma dispone, in verbis:

«Podrá deducirse la acción que tienda a obtener una sentencia meramente declarativa, para hacer cesar un estado de incertidumbre sobre la existencia, alcance o modalidades de una relación jurídica, siempre que esa falta de certeza pudiera producir un perjuicio o lesión actual al actor y éste no dispusiere de otro medio legal para ponerle término inmediatamente».

\section{UN ITINERARIO POR LA JURISPRUDENCIA DE LA CORTE SUPREMA DE JUSTICIA DE LA NACIÓN}

Para no exceder las pautas de extensión fijadas, en el presente trabajo omitiremos abordar las vivencias de la acción declarativa con anterioridad al año 1985, periodo temporal en el que, primeramente, no era considerada un proceso contencioso y luego, tímidamente, y si bien se fue abriendo la percepción en cuanto a su naturaleza de "caso judicial», se rechazaba la posibilidad de ejercer control de constitucionalidad en las acciones declarativas normadas en el art. 322 del C.P.C.C.N. ${ }^{1}$

Del lapso previo a 1985 sólo tomaremos el caso «Hidronor S.A. c/ Provincia de Neuquén", que - como veremos - ofrece interesante materia prima contenida no ya en el resolutorio, sino en la opinión del entonces Procurador General de la Nación.

Además, abordaremos sucesivamente las siguientes causas, además de las referencias a otros casos que se formularán a pie de

1 Se ha enseñado que las acciones declarativas han discurrido tres períodos en su historia vivencial: el primero se extiende hasta el año 1967, fecha en que la reforma al C.P.C.C.N. incorporó la acción declarativa como proceso judicial en el art. 322; el segundo finaliza en 1985 y, en él, la Corte no admite el control de constitucionalidad en las acciones declarativas reguladas en dicho artículo; el tercero de ellos comienza a partir de 1985 [cfr. BIANCHI, Alberto B.: "De la acción declarativa de certeza a la acción declarativa de inconstitucionalidad (La conversión del caso federal en caso judicial)", El Derecho, 22/02/2001, Buenos Aires (en adelante: Bs. As.), República Argentina (en lo sucesivo: Rep. Arg.), pág. 3]. 
página: «Provincia de Santiago del Estero c/ Estado Nacional y/o Yacimientos Petrolíferos Fiscales s/ acción de amparo"; "Lorenzo, Constantino c/ Nación Argentina»; "Klein, Guillermo Walter»; "Fábrica Argentina de Calderas S.R.L. c/ Provincia de Santa Fe»; "Gomer S.A. c/ Provincia de Córdobai; "Newland, Leonardo Antonio c/ Provincia de Santiago del Estero»; "Asociación Civil Escuela Escocesa San Andrés y otros c/ Provincia de Buenos Aires y otra»; "Asociación de Grandes Usuarios de Energía Eléctrica de la República Argentina c/ Provincia de Bs. As. y otro"; "Provincia de Río Negro c/ Nación Argentina»; "Iribarren, Casiano Rafael c/ Provincia de Santa Fe"; "Fayt, Carlos S. c/ Estado Nacional"; y "Palópoli, Hugo Daniel c/ Provincia de Buenos Aires s/ acción declarativan.

Obviamente, el señalamiento que ofreceremos no tiene (ni pretende tener) visos de exhaustividad, sino y solamente, busca constituirse en un muestrario referencial de la evolución jurisprudencial que sobre la materia ha evidenciado la Corte a partir de la preindicada fecha (1985), incluyendo algunos fallos de reciente data. Veamos:

\section{1. «Hidronor S.A. c/ Provincia de Neuquén"}

Como anunciábamos, el valor de esta causa no reside en el acto jurisdiccional de la sentencia que, por lo demás, se redujo a un mero proveído emitido por la Corte el 28/02/73 por el que tuvo por desistido el proceso, sino en el brillante dictamen del entonces Procurador General de la Nación, Dr. Eduardo H. Marquardt, pieza jurídica (expedida el 17/12/71) que proporcionó una serie de pautas de singular valía respecto de la acción declarativa, que fue tomada como obligado marco referencial en fallos posteriores.

Brevemente descriptos, los hechos de la causa indicaban que, ante la intimación que la Provincia de Neuquén formulara a la Sociedad Anónima Hidronor Hidroeléctrica Norpatagónica [en adelante: Hidronor S.A.] para que ésta abone una determinada suma de dinero en concepto de impuesto de sellos por el contrato celebrado entre dicha sociedad y la empresa constructora de El Chocón (Impregilo Sollazzo S.A.), pago que Hidronor S.A. se negaba a formalizar por considerar que la provincia carecía de facultades para imponer el mencionado gravamen (conclusión que el ente social asumía a partir de lo dispuesto por el art. 12 de la Ley $n .^{\circ} 15.336$, por la Ley $n .^{\circ} 17.574$ y por el contrato de concesión aprobado por el Decreto $\left.n .^{\circ} 8.053 / 68\right)$ y frente al hecho de que tal provincia aún no ejecutaba judicialmente el cré- 
dito que alegaba (mas no cesaba de reclamar su pago en sede administrativa), Hidronor S.A. planteó en su contra una acción declarativa (en los términos del art. 322 del C.P.C.C.N.), invocando la incertidumbre que la situación le generaba y solicitando de la Corte que estableciera la invalidez constitucional de los impuestos mencionados, en cuanto aplicables a la accionante.

Luego de transitar un interesante itinerario por diversas cuestiones, sin omitir una ilustrada referencia a la jurisprudencia de las Cortes Supremas argentina y de los EE.UU., compendió ciertos patrones y propuso las siguientes conclusiones, en las que subyace su visión relativa a que la acción mere declarativa entraña un caso contencioso $y$, en su marco, es factible el ejercicio del control de constitucionalidad2:

- El sistema de control constitucional vigente en el orden nacional impide que se dicten sentencias que priven de valor erga omnes a las normas impugnadas y obsta a la emisión de pronunciamientos sobre agravios meramente conjeturales e hipotéticos.

- La acción de mera certeza iniciada sobre la base de un interés sustancial concreto y definido y con efecto limitado a una declaración válida únicamente inter partes constituye causa en los términos de la Ley Fundamenta.

- La acción declarativa reglada en el art. 322 del C.P.C.C.N. se refiere tanto a las relaciones jurídicas de derecho privado como a las de derecho público; y si aquélla se emplea para impugnar la constitucionalidad de leyes, no se opone a ello la presunción de constitucionalidad de éstas, en virtud de la naturaleza declarativa de dichas acciones, que hace que durante la tramitación de la causa la ley pueda ser igualmente ejecutada, no asi después de resuelta su inconstitucionalidad por sentencia pasada en autoridad de cosa juzgada, que desde luego hace desaparecer la presunción.

- Por análogas razones, ya en materia fiscal, sostuvo que el principio solve et repete ${ }^{3}$ no obstaba al uso de la acción,

2 El dictamen puede ser consultado en La Ley, t. 154, Bs. As., Rep. Arg., págs. 515 y ss., o en Fallos, 307: 1387.

3 Para graficar ejemplificativamente lo que afirmábamos en punto a la elevada cotización prospectiva que adquiriria el dictamen comentado, valga evocar que la Corte - más de 15 años después - en el caso "Newland" (Fallos, 310: 606 
excepto en las hipótesis en que la ley prescribiera lo contrario.

En definitiva, y ya en conexión concreta con los actuados respecto de los que dictaminaba, opinó que la acción declarativa intentada se sustentaba en interés legítimo y concreto; que comprendía cuestiones de carácter federal y estaba dirigida contra una provincia; y que configuraba un caso o causa con arreglo a los (entonces) arts. 100 y 101 (hoy, arts. 116 y 117) de la Constitución Nacional [en lo sucesivo: C.N.] y 2 de la Ley $n .^{\circ} 27$, cuyo conocimiento caía bajo la competencia originaria y exclusiva de la Corte.

A partir de todo lo expuesto en la esclarecida opinión glosada precedentemente, Bidart Campos ${ }^{4}$ extrajo que parecía perder asidero la negativa a reconocer la procedencia del control de constitucionalidad dentro del proceso declarativo de certeza. Tenía razón.

\section{2. «Provincia de Santiago del Estero c/ Estado Nacional y/o Yacimientos Petrolíferos Fiscales s/ acción de amparo"}

En «Provincia de Santiago del Estero c/ Estado Nacional y/o Yacimientos Petrolíferos Fiscales s/ acción de amparon ${ }^{5}$ (del 20/08/85), la C.S.J.N. admitió - siguiendo el dictamen del Procurador General - su competencia originaria en la demanda instaurada.

La cuestión versaba sobre el dictado de la Ley $n .^{\circ} 5.464$ (de la provincia actora), por la cual se creaba el Departamento de Control de Combustibles, que tendría a su cargo - inter alia- el contralor cualitativo y cuantitativo de los combustibles líquidos, estableciéndose como retribución por esos servicios, una tasa del $5 \%$ sobre el precio de las naftas "súper" y "común" y del 2,5\% sobre el gasoil. Ante tales circunstancias, la divisional Salta de Yacimientos Petrolíficos Fiscales [en lo sucesivo: Y.P.F.] exhortó - vía telegrama- a los expendedores

- vid infra, subap. II.7-) adhirió expresamente al criterio expuesto en tal dictamen (entre otros puntos, acerca de la pauta solve et repete) y dejó en el camino la posición que el propio Tribunal (con diferente integración) sustentara desde el caso "Bridas c/ Provincia de Neuquén" (Fallos, 305: 1715), que también será, más adelante, objeto de breve referencia (ver infra subap. II.7).

4 BIDART CAMpos, Germán J.: "La acción declarativa de certeza y el control de constitucionalidad", La Ley, loc. cit. en nota 2, pág. 518.

5 Fallos, 307: 1379. 
de combustibles a abstenerse de modificar sus precios, bajo apercibimiento de aplicarles las sanciones fijadas en la Resolución de la Secretaría de Energía $n .^{\circ} 125 / 71$. Ante el requerimiento que a la empresa estatal formulara la actora en autos para que ratificara o rectificara dicha medida, aquélla reiteró su posición alegando que obedecía a directivas del Ministerio de Obras y Servicios Públicos de la Nación, fundadas en lo dispuesto por el art. 22, inc. 31, de la Ley Nac. n. ${ }^{\circ} 22.520$ (t.o. en 1983).

La Corte advirtió que la actora perseguía una declaración preventiva que impidiera que, en la oportunidad de ponerse en vigencia la ley que dictó su legislatura, el Estado Nacional concretara las medidas referidas precedentemente (considerando $4 . .^{\circ}$ ) y que se trasuntarían en no proveer "carburantes o productos e imponer sanciones" (ver considerando $3 .^{\circ}$ ).

Juzgó, entonces, que existía una solicitud de declaración de certeza, que no tenía carácter simplemente consultivo ni entrañaba una indagación meramente especulativa, sino que respondía a un "caso" $e$ intentaba precaver los efectos de un acto en ciernes y fijar las relaciones legales que vinculaban a las partes en conflicto (considerando $4 .^{\circ}$.

Con un interesante y valioso desapego por el rigorismo formal, prescindió del nomen iuris dado por la accionante a su pretensión (articulada primigeniamente como amparo/6, recanalizándola para subsumirla en el radio de cobertura de la acción declarativa regulada en el art. 322 del C.P.C.C.N., a la que estimó como un canal apto para evitar el eventual perjuicio denunciado por la actora, quien planteaba ante los estrados del Tribunal una relación jurídica discutida o incierta, evidenciándose la convergencia de un interés real y concreto susceptible de protección legal actual 7 (considerando $5 .^{\circ}$ ), con lo que puede afirmarse que inauguró una suerte de etapa revisionista de su anterior postura negatoria en punto a la potencialidad de la acción declarativa para efectuar, por su intermedio, control de constitucionalidad.

6 No es irrazonable pensar que el planteo originario de la accionante (por la vía del amparo) era el camino correcto para el desenvolvimiento de su pretensión.

7 El Tribunal expresó que, de tal modo, se configuraban las exigencias que la Corte Suprema de los EE.UU. consideró en "AEtna Life Insurance Co. c/ Havorth", 300 U.S.227), es decir: (a) actividad administrativa que afecta un interés legítimo; (b) que el grado de afectación sea suficientemente directo; $y$ (c) que aquella actividad tenga concreción bastante. 
Aunque colateralmente, la Corte reiteró que el amparo es procedente en litigios que caen bajo su competencia originaria (considerando $6 .^{\circ}$ ), admitiendo, además, que dicha acción - al igual que la declarativa - tiene una finalidad preventiva y no requiere la existencia de daño consumado en resguardo de los derechos (considerando $7 .^{\circ}$.

En definitiva, $y$ en tren de concretar el reencasillamiento procesal de la acción instada, concedió a la demandante el plazo de diez (10) días para encauzarla por la vía del juicio sumario ${ }^{8}$-demanda declarativa establecida en el mencionado art. 322 de la Ley ritual nacional-9.

\section{3. «Lorenzo, Constantino c/ Nación Argentina»}

En la causa "Lorenzo, Constantino c/ Nación Argentina»" (del 12/12/85), la Corte desestimó la demanda entablada por el actor contra el Poder Ejecutivo Nacional por la inconstitucionalidad de la Ley Nac. $n .^{\circ} 23.172$-que aprobó el Tratado de Paz y Amistad firmado con Chile - y la nulidad de los Decretos-Leyes n.os. 21.178/56 y 2.191/57 que, a juicio del peticionario, destruian la base territorial de la Provincia de Santa Cruz. En sustento de su pretensión, invocaba el derecho de defender las instituciones y la integridad de la Nación y se apoyaba en lo preceptuado por los arts. 21 y 33 de la Ley Fundamental.

Para fundar su solución desestimatoria (que confluyó en la decisión de que no existía causa de carácter contencioso), la Corte reenvió a lo resuelto in re "Baeza, Anibal Roque c/ Gobiérno Nacional»11,

8 Reenvió - inter alia - a lo resuelto en Fallos, 250: 154.

9 La mayoría estuvo integrada por J. S. CABALlero, Belluscio, FAYT Y BACQUÉ. Por su voto lo hizo PeTRACCHI, quien si bien concurrió a la solución mayoritaria en el sentido de conceder a la actora el plazo de diez días para que encauzara su demanda por la senda del proceso sumario, mocionaba disponer -ademásque, mientras se sustanciaba la causa, Y.P.F. se abstuviera de toda medida que pudiere implicar el cierre de las bocas de expendio de combustibles en la Provincia de Santiago del Estero o la privación de la provisión de productos a aquéllas.

10 Fallos, 307/2384.

11 Fallos, 306: 1125. En este pronunciamiento, del 28/08/84, la Corte por mayoría (J. S. Caballero, Carrió y Petracchi) desestimó el recurso de hecho articulado por el actor (quien en $1 .^{a}$ instancia dedujo acción de amparo con el objeto 
precedente en el que sostuvo que el Poder Judicial de la Nación conferido a ella misma y a los tribunales nacionales (entonces arts. 94, 100 y 101 de la C.N. -actuales arts. 108, 116 y 117, respectivamente-) se define como el que se ejercita en las causas de carácter contencioso a las que alude el art. 2 de la Ley Nac. $n .{ }^{\circ} 27$, es decir, aquéllas en las que se persigue en concreto la determinación del derecho debatido entre partes adversas, lo que no se configura cuando se procura la declaración general y directa de inconstitucionalidad de las normas o actos de los otros poderes (considerando $2 .^{\circ}$ ).

Sin embargo, y especificamente en el asunto que aquí interesa, dejó a buen resguardo que las consideraciones precedentes no tienen por corolario que en el orden nacional no exista la acción declarativa de inconstitucionalidad, mas aclarando que resultaba preciso disipar la confusión entre peticiones abstractas y generales de inconstitucionalidad, que no pueden revestir forma contenciosa dada la ausencia de interés inmediato del peticionante, y las acciones determinativas de derechos de base constitucional cuya titularidad alega el demandante y que tienden a prevenir o impedir las lesiones a tales derechos, pasando a citar como ejemplos de estas últimas a la acción de mera certeza y al amparo (considerando $4 .{ }^{\circ}$ ).

de que se declarase la inconstitucionalidad del Decreto Nac. $n .^{\circ} 2.274 / 84$, por el cual el P.E.N. convocó a una consulta popular respecto de los términos del arreglo limítrofe con Chile por la zona del Canal de Beagle), entendiendo que no existía "causa" o "caso" en los términos contemplados por los (ex) arts. 100 y 101 (hoy, arts. 116 y 117$)$ y 2 de la Ley Nac. $n .^{\circ} 27$, además de que el actor no habia solicitado la tutela específica del supuesto derecho que invocaba.

En disidencia, FAYT - citando el dictamen del Procurador General elaborado en "Hidronor S.A." - consideró que sí existía caso judicial y que el control de constitucionalidad era viable en el ámbito de la acción establecida en el art. 322 del C.P.C.C.N., pero que, como la convocatoria dispuesta por el P.E.N. (a través del Decreto Nac. $\left.n .^{\circ} 2.272 / 84\right)$ importaba una simple consulta no vinculante y no un referéndum, no se estaba ante la presencia de un acto de decisión en la formación por el pueblo de la voluntad legislativa del Estado, razón por la cual no quedaba alterado el contenido formal y material del art. 22 de la C.N.; todo lo que lo condujo a desestimar la queja articulada.

Por último, BELLUSCIO - también en disidencia - propiciaba revocar, por arbitraria, la sentencia de $2 .^{a}$ instancia y confirmar la de $1 .^{a}$, que había admitido que el actor tenía un interés que lo legitimaba para actuar; mas no ingresó en el análisis de la cuestión relativa al control constitucional en el marco de la acción declarativa de certeza. 


\section{4. «Klein, Guillermo Walter»}

En la causa "Klein, Guillermo Walter" (del 29/08/86)12, la Corte declaró que su pronunciamiento sería inoficioso ${ }^{13}$, pues no había ningún derecho debatido a determinar entre las partes ${ }^{14}$, sin perjuicio de lo cual, reafirmó el reconocimiento de la acción de mera certeza en materia constitucional, siempre que se den sus requisitos (para lo que citó los casos "Provincia de Santiago del Estero" y "Lorenzo») -ver considerando 13, tramo in fine-.

Por lo demás, dejó en claro que en el caso de autos (en el que se había deducido una acción de amparo admitida estimatoriamente en ambas instancias de mérito) el Tribunal no podía poner en juego la facultad de asignarle al amparo articulado, el carácter de acción meramente declarativa, mutación que sólo puede ser ejercitada en causas de jurisdicción originaria (parte final del considerando 14).

\section{5. «Fábrica Argentina de Calderas S.R.L. c/ Provincia de Santa Fe»}

En la causa del epígrafe, cuyo resolutorio se expidiera el $19 / 12 / 86^{15}$, la Corte encuadró el planteo de la accionante - con prescindencia del nomen iuris seleccionado por ésta- en el marco de lo pautado en el art. 322 del C.P.C.C.N., siguiendo el aspecto sustancial de la petición incoada, que perseguía la tutela jurisdiccional consistente en una declaración de certeza que no la obligue en el futuro, $y$

\section{Fallos, 308: 1489.}

13 Recuérdese, sintéticamente y en cuanto a la plataforma fáctica del caso, que la Comisión creada por la Cámara de Diputados de la Nación para investigar las presuntas irregularidades cometidas en la transferencia al Estado de la Compañía İ́talo Argentina de Electricidad, aquélla allanó el estudio jurídico del actor y secuestró una cantidad de documentos que allí se encontraban, lo que motivó la articulación de la acción de amparo por parte del Dr. Klein, orientada a que se declarara la ilegitimidad del procedimiento efectuado por dicha Comisión $y$, en consecuencia, se ordenara a la Cámara de Diputados la restitución de los instrumentos secuestrados.

14 Explicó la Corte que si el amparista obtuviese sentencia declarativa en su favor, ésta ya no podría producir efectos concretos en su relación con la Cámara de Diputados de la Nación, mientras que darle eficacia contra los representantes del Estado, y sea el Ministerio Público, en los procedimientos penales que se siguen, implicaría atribuirle el carácter de una declaración de inconstitucionalidad genérica y oponible erga omnes (considerando 13).

15 Fallos, 308: 2569. 
en su calidad de empleadora, a abonar salarios correspondientes a una jornada máxima de 48 hs. semanales como contraprestación por tareas prestadas en la jornada reducida de $44 \mathrm{hs}$. por semana.

Según el Tribunal, la actora dedujo dos pretensiones netamente diferenciables: (a) la declaración de inconstitucionalidad de la Ley Prov. $n .^{\circ} 9.497$, que reimplantaba su similar $n .^{\circ} 7.197$ y, que resultaba lesiva de lo dispuesto por los arts. 31 y 67, inc. 11 (hoy, art. 75, inc. 12), de la C.N.; y (b) la repetición de las sumas por ella abonadas a su personal en virtud de la norma cuestionada (considerando $2 .^{\circ}$ ).

Al respecto, entendió la Corte que la declaración de inconstitucionalidad pretendida no tenía simplemente un carácter consultivo ni importaba una indagación meramente especulativa, sino que correspondia a un "caso" en el cual el titular de un interés jurídico concreto buscaba fijar las modalidades de la relación jurídica que mantenía con sus dependientes, que conectaba en forma inmediata con una ley provincial a la que la peticionaria atribuía ilegitimidad y lesión al régimen constitucional federal (considerando $3 .^{\circ}$ ).

En definitiva, el Tribunal acogió la declaración de inconstitucionalidad de la referida ley provincial y rechazó la pretensión dirigida a que la accionada restituyera a la actora las sumas abonadas en exceso a causa del cumplimiento de la norma cuestionada. Como sostiene Bianchi, la Corte introdujo - fuera de un obiter- el control de constitucionalidad en el marco de una acción que involucraba una petición de certeza, aunque - como anunciábamos - la demandante no había articulado formalmente una acción declarativa ${ }^{16}$.

\section{6. "Gomer S.A. c/ Provincia de Córdoba"}

En "Gomer S.A. c/ Provincia de Córdoba»17 (03/02/87), la empresa accionante dedujo acción declarativa de inconstitucionalidad, sin verbalizar esa denominación ni hacer referencia al art. 322 del C.P.C.C.N., dirigida a que la Corte Suprema declarara improcedente el impuesto sobre los ingresos brutos establecido por la Provincia de Córdoba - mediante su código tributario-, sustentando su petición

\footnotetext{
17 El Derecho, t. 123, Bs. As., Rep. Arg., págs. 424/425.
}

pág. 4.

16 BIANCHI, Alberto B., op. cit. [«De la acción declarativa de certeza...»], 
en la incidencia que tal carga impositiva tendria sobre la actividad de comercialización de productos farmacéuticos efectuada en ese territorio.

Para resolver dicho caso, la Corte inaugura su sentencia con la siguiente afirmación: "Que de conformidad con la jurisprudencia del Tribunal existe en el orden nacional la acción declarativa de inconstitucionalidad y ella puede ser instaurada directamente ante esta Corte cuando se dan los requisitos que determinen su intervención en instancia originaria" - subrayado añadido - (considerando $1 .^{\circ}$ ). Pasa a citar los precedentes "Provincia de Santiago del Estero", "Lorenzo" y "Klein" -ya reseñados en este trabajo-, de lo que quizás pueda inferirse que el caso "Gomer" no es sino la reafirmación de una tendencia acuñada un año y medio atrás en «Provincia de Santiago del Esteron.

Lo cierto es que "Gomer" puede ser sindicado como el primer precedente en el que el Alto Tribunal construye su razonamiento sobre la base de admitir la posibilidad de ejercer control de constitucionalidad a través de la acción declarativa. Allí radica la importancia del escueto fallo, ya que, en punto al destino de la pretensión actora, la rechazó liminarmente sustentándose en que ella no reunía los requisitos de admisibilidad individualizados en el art. 322 del C.P.C.C.N., en cuyo molde - reiteró- debía gestarse y, por tanto, a ella quedar ajustada, la acción declarativa de inconstitucionalidad.

En el dictamen del Procurador Fiscal de la Nación - al que el fallo reenvía - se sistematiza la trilogía de requisitos exigible para la procedencia de las acciones meramente declarativas:

a) Estado de incertidumbre sobre la existencia, alcance y modalidad de una relación jurídica;

b) Interés jurídico suficiente en el accionante, en el sentido de que la falta de certeza pudiera producirle un perjuicio o lesión actual;

c) Interés específico en el uso de la vía declarativa, es decir, que el actor no dispusiere de otro medio legal para ponerle término inmediatamente.

Desde nuestro punto de vista, el fallo representó un avance hacia la amplitud de las facultades de contralor constitucional de la Corte, pues ya sin lugar a dudas el Tribunal admitió expresamente la posibilidad de hacerlo ante la articulación directa (en instancia originaria) de una acción declarativa de inconstitucionalidad. Como verifica Bianchi, 
el Tribunal introdujo formalmente el control de constitucionalidad dentro de la acción declarativa en el holding de su pronunciamiento ${ }^{18}$.

Comentando el fallo, Bidart Campos sostuvo cautelosamente que no puede decirse que en el orden federal haya acción declarativa de inconstitucionalidad, sino sólo que existe la de certeza regulada del modo estipulado en el art. 322 del C.P.C.C.N., acción que puede también ser usada - siempre que se den los requisitos generales de procedencia - en cuestiones de inconstitucionalidad ${ }^{19}$. Con tales prevenciones, subraya el autor citado que existe una especifica modalidad de acción declarativa de inconstitucionalidad «dentro» de la acción declarativa de certeza ${ }^{20}$ [subrayado y entrecomillado del original].

Por nuestra parte, y vis-à-vis la contundente aseveración del Tribunal, nos parece que la Corte ha declarado que si existe dicha acción, mas queda encapsulada procesalmente (y en cuanto a los requisitos que debe reunir) en la previsión que el código ritual dispensa a la acción meramente declarativa.

\section{7. «Newland, Leonardo Antonio c/ Provincia de Santiago del Estero»}

La solución dispensada en este caso, fallado por la Corte el $19 / 03 / 87^{21}$, se encarama como un precedente importante en el que el Tribunal (con otra composición) mudó un restrictivo y censurable criterio jurisprudencial (sentado in re "Bridas c/ Provincia de Neuquén" $)^{22}$ consistente en que, dado el carácter subsidiario de la pretensión declarativa, ésta quedaba relegada por otras vías legales -igualmente aptas - para efectuar planteos relativos a cuestiones tributarias, además de que debía cumplirse con la regla solve et repete previo a acudir a la justicia y, luego $y$ en su caso, intentar la restitución de lo oblado.

Brevemente presentado, el encuadre fáctico de la causa consistía en lo siguiente: El actor interpuso acción meramente declarativa

18 BIANCHI, Alberto B., op. cit. [«De la acción declarativa de certeza...»], idem.

19 BIDART CAMPOS, Germán J.: ¿Hay en el orden federal acción declarativa de inconstitucionalidad?, El Derecho, loc. cit. en nota 17, pág. 424.

20 ídem.

21 Fallos, 310: 606.

22 Fallos, 305: 1715. 
ante la Corte, frente a lo cual la Provincia demandada opuso las excepciones de incompetencia, alegando en su sustento que sólo puede accionarse en instancia originaria ante el Alto Tribunal por la repetición de impuestos abonados espontáneamente, y de falta de legitimación activa, invocando a su respecto que la admisión de una acción meramente declarativa en materia tributaria importaría desconocer la vigencia del principio solve et repete.

Luego de considerar que se encontraban reunidos los requisitos establecidos por el art. 322 del C.P.C.C.N. para la procedencia formal de la acción meramente declarativa (considerando $3 .^{\circ}$ ) y de concluir en la existencia de "causa» en los términos de la Ley Fundamental (citando los precedentes "Provincia de Santiago del Estero" y "Fábrica Argentina de Calderas S.R.L.") -considerando $4 .^{\circ}-$, criteriosamente, la Corte entendió que la exigencia de cumplimiento previo de lo que constituye el objeto de la discusión implicaría desconocer la necesidad de tutela judicial que, en casos como el planteado en autos, tendía a dilucidar el estado de falta de certeza entre el contribuyente que cuestiona la actitud del Estado y este último (considerando $5 .{ }^{\circ}$ ).

Por fin, y dejando sentado que adoptaba el criterio expuesto por la Procuración General en el dictamen emitido en "Hidronor S.A." (que fuera tratado supra) y, expresamente, que abandonaba el sentado en Fallos, 305:1715 - tal como anticipábamos - (ver considerando $6 .^{\circ}$ ), desestimó las excepciones opuestas y mantuvo su competencia para entender en la causa.

\section{8. «Asociación Civil Escuela Escocesa San Andrés y otros c/ Provincia de Buenos Aires y otra»}

En sentido similar al evidenciado en "Newland", mas referido concretamente a la petición de concesión de una medida cautelar en una acción meramente declarativa, planteada ante la Corte y fundada en la pretendida inconstitucionalidad de la Ley Prov. (de Bs. As.) n. ${ }^{\circ}$ 10.427 en cuanto entrañaría una violación directa a la Ley Nac. n. ${ }^{\circ}$ 18.037 y a la C.N. (al obligar a suplantar el régimen previsional nacional por el sistema local), el 21/05/87 el Tribunal resolvió ${ }^{23}$ que existía "causa» en los términos de la Constitución (apoyándose en lo resuel- 
to en "Provincia de Santiago del Estero», "Fábrica Argentina de Calderas S.R.L." Y, precisamente, en "Newland") -considerando 1. - ; que se hallaban reunidos los recaudos de admisibilidad del art. 322 del C.P.C.C.N. ${ }^{24}$ (considerando $2 .^{\circ}$ ); afirmó su competencia para entender en el proceso, y desestimó la medida precautoria solicitada.

\section{9. «Asociación de Grandes Usuarios de Energía Eléctrica de la República Argentina (AGUEERA) c/ Provincia de Bs. As. y otro»}

Los hechos de la causa muestran que AGUEERA inició demanda contra la Provincia de Buenos Aires y el Ente Provincial Regulador Energético, con el objeto de que se declare la inconstitucionalidad de los Decretos-Ley n. os. $7.290 / 67$ y $9.038 / 78$ y del Decreto $n .^{\circ} 1.160 / 92$ de la mencionada provincia, por resultar violatorios de la C.N. y del orden normativo federal derivado de la Ley $n{ }^{\circ} 24.065$ y de sus normas reglamentarias y complementarias. La provincia accionada, por su parte, se presentó y articuló la excepción previa de falta de legitimación activa.

En un fallo tan breve como importante, emitido el 22/04/9725, la Corte recordó que el art. 43 de la C.N. faculta a interponer acciones de amparo contra cualquier forma de discriminación y, en lo relativo a los derechos que protegen al ambiente, a la competencia, al usuario y al consumidor, así como a los derechos de incidencia colectiva, legitima -además de al afectado y al Defensor del Pueblo- a "las asociaciones que propendan a esos fines, registradas conforme a la ley, la que determinará los requisitos y formas de su organización", concluyendo que la demandante se encontraba dentro de esas asociaciones, por cuanto habia sido creada por el Decreto Prov. n. $1.192 / 92$ con la finalidad de proveer a la defensa de los intereses de sus asociados, que son precisamente los grandes usuarios de electricidad (considerandos $3 .^{\circ}$ y $4 .^{\circ}$.

El Tribunal dejó aclarado que el hecho de que la actora haya demandado por la vía prevista en el art. 322 del C.P.C.C.N. no constituye óbice para la aplicación de aquel precepto, en virtud de la analogía entre dicha acción y la de amparo (considerando $5 .^{\circ}$ ).

24 Se separó, así, del dictamen del Procurador Fiscal de la Corte, que propiciaba (con sustento en lo resuelto en «Gomer») el rechazo liminar de la acción intentada, al juzgar no configurados los requisitos de admisibilidad determinados por el art. 322 del código ritual.

25 La Ley, t. 1997-C, Bs. As., Rep. Arg., págs. 322/323. 
Puso de manifiesto que tal analogía había sido advertida por la Corte al señalar que el pedido de declaración de inconstitucionalidad de una norma importa el ejercicio de una acción directa de inconstitucionalidad, de aquéllas que explícitamente ha admitido como medio idóneo - ya sea bajo la forma del amparo, la acción de mera certeza o el juicio sumario en materia constitucional- para prevenir o impedir las lesiones de derechos de base constitucional, reenviando - inter alia- al caso "Ravaglia y otros c/ Prov. de Santa Fe s/ amparo»" ${ }^{26}$ (id. considerando).

El fallo dice, además, que la acción declarativa, al igual que la de amparo, tiene una finalidad preventiva y no requiere la existencia de daño consumado en resguardo de sus derechos, citando el precedente de "Provincia de Santiago del Estero c/ Nación Argentina", concretamente, los considerandos $7 .^{\circ}$ del voto de la mayoría y del concurrente de Petracchi (id. considerando).

En definitiva, desestimó la excepción previa deducida por la demandada.

Permítasenos apuntar que se ha puntualizado, con acierto, que la institucionalización del amparo de los derechos de incidencia colectiva $-y$, agregamos por nuestra parte, la apertura jurisprudencial hacia la viabilidad de la acción declarativa de inconstitucionalidad para canalizar su protección - viene a vigorizar la función de contralor social de los gobernantes, lo que recibe complementación con la implementación de otros organismos de control27, como por ejemplo, la Audito-

26 En dicho pronunciamiento (del 06/10/94 - Fallos, 317: 1224-), escueto por cierto, la Corte rechazó in limine la demanda de amparo incoada por los actores (invocando sus respectivas condiciones de ciudadanos con derecho a voto en la Provincia de Santa Fe) contra dicha Provincia y su Poder Legislativo, por la omisión de modificar el art. 64 de la Constitución local que prohíbe la reelección inmediata de gobernador $y$ vicegobernador, solicitando se declare la inconstitucionalidad de dicha norma. El Tribunal desestimó la acción manifestando que los accionantes carecian de legitimación, y remitió - entre otros - a lo resuelto en "Polino" (que será brevemente referenciado en la nota 46), en el que la Corte reconoció haber admitido el ejercicio de "acciones directas de inconstitucionalidad" como medio idóneo - sea bajo la forma de amparo, de acción de mera certeza o de juicio sumario en materia constitucional- para prevenir o impedir las lesiones de derechos de base constitucional - vid. considerando $3 .^{\circ}$ del voto mayoritario-.

27 Quiroga LaviE, Humberto: "Nuevos órganos de control en la Constitución: el Defensor del Pueblo y el Ministerio Públicon, en el volumen colectivo La reforma de la Constitución, Rubinzal-Culzoni, Santa Fe, Rep. Arg., 1994, pág. 267. 
ría General de la Nación (art. 85 de la C.N.), el Defensor del Pueblo (art. 86 ibid.) y el Ministerio Público (art. 120 ibid.).

Para concluir, y en tren de brindar un concepto de interés difuso y colectivo o derecho de incidencia colectiva (como menciona el art. 43, párrafo segundo, de la C.N.), nos apoyamos en Bujosa Vadell, quien ha sostenido que "tal interés se refiere a la relación por la que un grupo más o menos determinado de personas pretende la evitación de un perjuicio o la consecución de un beneficio en relación con un objeto no susceptible de apropiación exclusiva o en relación con diversos objetos susceptibles de apropiación exclusiva pero cualitativamente idénticos» 28 .

\section{0. «Provincia de Río Negro c/ Nación Argentina»}

Tal causa fue fallada el $31 / 05 / 99^{29}$ de modo muy similar a la forma en que lo hiciera en "Provincia de Santiago del Estero v. Nación Argentina". La base fáctica de la cuestión era la siguiente: el Gobernador de la Provincia de Río Negro interpuso acción de amparo (art. 43 de la C.N.), en instancia originaria ante la Corte, con el objeto de que se declarara la inconstitucionalidad del art. 45 , párrafo $1 .^{\circ}$, de la Ley federal de radiodifusión $\left(\mathrm{n}^{\circ}{ }^{\circ} 22.285\right)$, de los decretos del P.E.N. n.os $310 / 98$ y 2/99, de las resoluciones de la Secretaría de Comunicaciones $n$.os $163 / 96$ y $2.344 / 98$ y de las $n$.os $16 / 99$ y 76/99 del COMFER, por ser violatorios de la Ley Fundamental y de varios tratados internacionales.

El Tribunal recordó su doctrina (de Fallos, 307:1379, es decir, el precedente mencionado en el párrafo anterior) en el sentido de que la acción de amparo, de manera general, es procedente en los litigios que caen dentro de la competencia originaria de la Corte porque de otra forma, en tales controversias quedarian sin protección los derechos de las partes en los supuestos contemplados por la Ley Nac. $n .^{\circ} 16.986$; de cualquier modo, advirtió que en el caso no se configuraban dichas circunstancias y se mostraban poco compatibles el régimen legal y los mecanismos previstos en la aludida Ley reglamentaria del amparo (considerando $4 .{ }^{\circ}$ ).

28 BUJOSA VADELL, Lorenzo M.: "Sobre el concepto de intereses de grupo difusos y colectivos", La Ley, 1997-F, Bs. As., Rep. Arg., pág. 1157.

29 Fallos, 322: 1135. 
Paralelamente, y en idéntico considerando, expresó que la acción declarativa de inconstitucionalidad que, al igual que el amparo, posee una finalidad preventiva y no requiere la existencia de daño consumado en resguardo de los derechos, constituye un medio plenamente eficaz y suficiente para satisfacer el interés de la accionante.

Por tanto, estimó que podía prescindirse válidamente del nomen iuris empleado por la interesada y atender a la real sustancia de la solicitud por medio del ejercicio de la acción declarativa regulada en el art. 322 del C.P.C.C.N. (considerando $5 .^{\circ}$ ), por lo que decidió correr traslado de la demanda, la que debería sustanciarse por la vía del proceso sumario, aunque rechazó la prohibición de innovar solicitada.

\section{1. «Iribarren, Casiano Rafael c/ Provincia de Santa Fe»}

Esta causa, fallada el 22/06/9930, se inició como consecuencia de la acción declarativa de certeza articulada por el Dr. Iribarren (juez de la Corte Suprema de Justicia santafecina) con el objeto de lograr un pronunciamiento que declare la inconstitucionalidad del art. 88 de la Constitución local en cuanto dispone el cese de la inamovibilidad de los magistrados a partir de los 65 años de edad si están en condiciones de obtener la jubilación ordinaria ${ }^{31}$.

La Corte, anticipando el carril a discurrir por la solución que luego propiciaría en el caso "Fayt" - que veremos a continuación-, reiteró que la declaración de certeza, en tanto no tenga carácter simplemente consultivo ni importe una declaración meramente especulativa y responda a un "caso" que busque prevenir los efectos de un acto en ciernes, al que se atribuye ilegitimidad y lesión al régimen constitucional, constituye causa en los términos de la Ley Funda-

30 Fallos, 322: 1253.

31 Es importante recordar que el actor obtuvo (varios años antes de la resolución sobre el fondo de la cuestión planteada en la acción declarativa) el dictado en su favor de una prohibición de innovar, con relación a las medidas que pudiera adoptar el Poder Ejecutivo provincial sobre la base del art. 88 de la Constitución local. Logró dicha protección cautelar el 22/12/92 (Fallos, 315: 2956), mientras que - como surge del texto - el resolutorio sustancial data del 22/06/99, lo que evidencia la excesiva prolongación de las acciones declarativas de inconstitucionalidad en el seno de la C.S.J.N. y la consecuente importancia de conseguir una tutela anticipada para mantener indemne el derecho cuya protección se intenta defender y evitar, así, un daño irreparable al peticionario. 
mental (citando los precedentes «Provincia de Santiago del Estero c/ Nación Argentina", "Newland" y "Estado Nacional c/ Provincia de Santiago del Estero" -este último, en Fallos, 310:2812-) -ver considerando $2 .^{\circ}-$.

$Y$ ya sobre el núcleo de la petición (validez constitucional del art. 88 de la Constitución santafecina que establece la pérdida de la inamovilidad de los jueces a los 65 años de edad si se encuentran en condiciones de acogerse a la jubilación ordinaria), sostuvo que dicha norma presenta una diferencia sustancial con el art. 99 , inc. $4 .^{\circ}$, de la C.N., ya que en modo ajeno a éste, el precepto provincial hace cesar la condición de inamovilidad del cargo para el magistrado que cumple 65 años, sometiéndolo sine die a permanecer en la función, con un carácter precario, sujetando ese estado al exclusivo arbitrio del Poder Ejecutivo (considerando $7 .^{\circ}$ ), precepto que choca frontalmente con el deber de asegurar la administración de justicia que la C.N. asigna a las provincias en el art. 5, ya que deja en manos de otros poderes la disposición de los cargos de los magistrados que arriban a determinada edad (considerando $8 .^{\circ}$ ).

Por último, y aclarando que su pronunciamiento no se asentaba en razones vinculadas a la conveniencia o inconveniencia de la norma en cuestión, sino en la comprobación de que ella colisiona con los principios de la Ley suprema federal, correspondía admitir la pretensión (considerando $13 .^{\circ}$ ) y, en consecuencia, la Corte - por mayoría ${ }^{32}$. declaró la inconstitucionalidad del aludido art. 88.

\section{2. «Fayt, Carlos S. c/ Estado Nacional»}

El caso "Fayt» representa un jalón sui generis en la evolución del tratamiento jurisprudencial de la acción declarativa, pues si bien condujo teóricamente a la declaración de nulidad de la norma en crisis (nada más y nada menos que un precepto constitucional), merece ser

32 La mayoría del Tribunal estuvo constituida por NAZARENo, MOLINÉ O'CONNOR Y BOggIaNo. En voto conjunto - confluente - lo hicieron PETRACCHI y BOSSERT. Concurrentemente, pero en voto individual, VAZZUEZ desnudó ante tempus lo que habría de ser la percepción decisoria de la Corte en "Fayt" y, curiosamente, propició considerar «nula de nulidad absoluta la cláusula contenida en el art. 99, inc. $4^{\circ}$, apartado tercero de la Constitución Nacional (art. 6 de la ley 24.309)" y admitir la demanda, declarando la inconstitucionalidad del art. 88 de la Constitución santafecina. Por último, BELLUSCIO votó en disidencia y FAYT no participó del acuerdo. 
incluida en este señalamiento (no obstante que la acción no haya sido planteada en la instancia originaria y exclusiva de la Corte) por la enorme trascendencia de la cuestión en torno de la cual giró el problema (que incluye la posibilidad de ejercer control de constitucionalidad sobre la labor del poder constituyente derivado), las impredecibles proyecciones que la solución diseñada por el Tribunal puede provocar en el futuro, la convergencia de una posición activista por parte del máximo Tribunal argentino - que no pocos han tildado de respuesta corporativista $-y$, aun cuando no abiertamente, la asunción de un criterio progresista - que ojalá se mantenga en otras causas - para la visualización de ciertos asuntos otrora declarados no judiciables.

Moviéndonos hacia el caso concreto, cabe evocar que el Dr. Carlos S. Fayt (ministro de la Corte Suprema de Justicia de la Nación) promovió acción declarativa con el fin de obtener la nulidad -en los términos del art. 6 de la Ley Nac. . $^{\circ} 24.309-$ de la reforma introducida en el art. 99 , inc. $4 .^{\circ}$, párrafo $3 .^{\circ}$, de la C.N. en cuanto importa una restricción no habilitada a la garantía de inamovilidad de los jueces consagrada en el art. 110 del actual texto constitucional (ex art. 96), al disponer que un nuevo nombramiento, precedido de acuerdo del Senado, será necesario para mantener en el cargo a cualquier magistrado una vez que cumpla la edad de 75 años.

El Juzgado Federal Contencioso-administrativo n. ${ }^{\circ} 7$, en sentencia del $30 / 04 / 98^{33}$, hizo lugar a la acción declarativa iniciada por el $\mathrm{Dr}$. Fayt, estableciendo a su respecto ${ }^{34}$ la nulidad, en los términos del art. 6 de la Ley Nac. $n .^{\circ} 24.039$, de la reforma introducida en el art. 99, inc. $4 .^{\circ}$, párrafo $3 .^{\circ}$, del nuevo texto de la Constitución Nacional.

A su turno, y apelado que fue el pronunciamiento de la instancia de origen, la sala III de la Cámara Nacional en lo Contencioso-administrativo Federal, en fecha 19/11/98 la revocó ${ }^{35}$, desestimando el pedido de nulidad, sin perjuicio de hacer lugar a la demanda por entender que el art. 99 , inc. $4 .^{\circ}$, párrafo $3 .^{\circ}$, de la C.N. no resultaba aplicable al actor.

La Corte, en fallo del 19/08/99, admitió el recurso extraordinario, revocó la sentencia resistida y, por mayoría, declaró la nulidad de la

33 El fallo puede ser consultado en La Ley [Suplemento de Derecho Constitucional, 18/08/98, Bs. As., Rep. Arg., págs. 3/9.

34 La expresión "a su respecto», ¿significa que la declaración de nulidad a la que se referia el fallo beneficiaba sólo a Fayt?

35 Ver La Ley, t. 1999-C, Bs. As., Rep. Arg., págs. 219 y ss. 
reforma introducida en art. 99 , inc. $4 .^{\circ}$, párrafo $3 .^{\circ}$ de la C.N. -en la disposición transitoria undécima - al art. $110 \mathrm{ibid}$.

El criterio mayoritario fue sustentado por Nazareno, Moliné O'Connor, Belluscio, Boggiano y López. Vázquez votó individual y concurrentemente y Bossert lo hizo en disidencia parcial ${ }^{36}$. Por último, cabe recordar que -en un gesto digno de encomio ${ }^{37}$ - Petracchi se había excusado, y aun cuando no fue aceptada su excusación (por auto del 19/08/99), igualmente no participó del acuerdo.

Los argumentos del Tribunal, en lo que al voto de la mayoría se refiere, pueden sintetizarse de la siguiente manera:

- Al declarar la necesidad de la reforma constitucional y fijar los límites de la Convención por medio de una ley, el Congreso ha admitido el carácter justiciable de los límites del poder reformador $y$, en tanto previó la sanción de nulidad de las "modificaciones, derogaciones y agregados" que se realizaran apartándose de la competencia establecida (art. 6, Ley Nac. n. ${ }^{\circ}$ 24.309), presupuso la existencia de un poder dotado de suficientes facultades para controlar el alcance de las disposiciones y de las derogaciones adoptadas (considerando $6 .^{\circ}$ ).

- La sanción explícita de nulidad contenida en dicho art. 6 de la ley declarativa de la necesidad de la reforma revela el carácter de restricción explícita que el Congreso atribuyó a aque-

36 Bossert sostuvo, en sustancia, que la límitación a la inamovilidad de los magistrados impuesta por el art. 99 , inc. $44^{\circ}$, de la Constitución reformada, ha sido establecida respecto de quienes después de su sanción cumplan la edad de 75 años, alcanzando tanto a los jueces designados con posterioridad a la reforma constitucional como a quienes lo han sido con anterioridad a la misma, pero impone como condición un hecho incierto y futuro, limitando su aplicación a quienes luego de la reforma cumplan la edad establecida. De ello extrae que tal limitación no afecta la inamovilidad del juez Fayt puesto que éste, nacido el 1 de febrero de 1918, ya había superado esa edad al sancionarse la reforma (considerando 9).

37 Con crudo realismo, expresó que uno se advierte por qué los jueces de esta Corte, que se excusaron cuando estaba en juego la garantía de la intangibilidad de los haberes de los jueces nacionales [se refiere a Fallos, 311: 1946 y 2788; y 318: 249], no deberían adoptar igual criterio cuando se discute la garantía de la inamovilidad de aquéllos (de igual o mayor entidad que la primera)" (considerando $6 .^{\circ}$ del voto en disidencia de PETRACCH en el resolutorio del 19/08/99, por el que la Corte desestimó la reposición articulada por el Procurador General de la Nación contra el decisorio del 14/07/99 que rechazó in limine su pedido recusatorio de los magistrados del Tribunal). 
llo que alterase o excediese el marco de la habilitación (considerando $10 . \%$.

- El control de los límites de la Convención exige profundizar la intención de quienes fijaron los puntos habilitados para su revisión y no la de los convencionales (considerando $9 .^{\circ}$ ).

- La reforma introducida en el art. 99 , inc. $4 .^{\circ}$, párrafo $3 .^{\circ} y$ de la cláusula transitoria undécima de la C.N. es nula de nulidad absoluta dado que una alteración tan sustancial no reconoce habilitación suficiente en las facultades implícitas derivadas de la expresa atribución de reformar el régimen de designación de los magistrados federales, además de que en ningún párrafo de los puntos "l» y "J" del "Núcleo de Coincidencias Básicas" - relativos a la designación y a la remoción de aquéllosaparece algún contenido que pudiera interpretarse racionalmente como relativo a la posibilidad de estipular un término a la garantía de inamovilidad de ellos (que es inherente a la naturaleza del Poder Judicial de la Nación y configura uno de los principios estructurales del sistema político establecido por los constituyentes de 1853) con motivo del cumplimiento de una determinada edad (ver -inter alia- considerando 12). En el mismo sentido, expresó el voto en mayoría que el ex art. 96 (actual art. 110) no fue incluido entre las cláusulas que la Convención estaba habilitada a revisar (considerando 11).

Sin perjuicio de coincidir con algunos aspectos del fallo de la Corte ${ }^{38}$, y preguntándonos si no habria sido más correcto e institucionalmente saludable que los magistrados que la integran (y que pue-

38 El Tribunal, en postura aperturista, modificó la doctrina tejida en torno de la insusceptibilidad de control de constitucionalidad respecto de la reforma constitucional, plasmada - v.gr. - en "Soria de Guerrero, Juana Ana c/ S.A. Bodegas y Viñedos Pulenta Hnos.n (Fallos, 256: 556), precedente en el que estimó que no constituye cuestión justiciable la consistente en el modo como el Poder Legislativo cumplió las prescripciones constitucionales atinentes al procedimiento adoptado en la formación y sanción de las leyes, principio que sólo cedería en el supuesto de demostrarse la falta de concurrencia de los requisitos mínimos e indispensables que condicionan la creación de la ley (considerandos $3 .^{\circ}$ y $1 .^{\circ}$ ). Añadió que si ello es así con respecto a la observancia del procedimiento constitucional vigente para las Cámaras del Congreso, con mayor razón la intervención de la Corte tampoco es pertinente para decidir - como se pretendía - si el art. 14 nuevo de la Constitución Nacional fue sancionado de conformidad con las normas del reglamento interno dictado por la Convención Constituyente de 1957 relativas a la exigencia de aprobación, por dicho cuerpo, de las versiones taquigráficas de sus sesiones 
den quedar comprendidos $-y$ beneficiados - por la interpretación desplegada y la solución proporcionada por el Tribunal) se hubiesen excusado de intervenir en el proceso, dando paso a una integración del cuerpo por conjueces, creemos que se ha abierto una brecha peligrosa. Practicando solamente un ejercicio intelectual teórico, reflexionemos - v. gr. - en la prohibición de modificar la parte primera de la Constitución vehiculada por la Ley Nac. $n .^{\circ} 24.309$ (art. 7) y los contrabandos normativos que sólo geográficamente emplazados en la parte orgánica, en realidad se refieren a los contenidos de la primigenia parte dogmática, modificándolos, complementándolos, ampliándolos, etc. Repárese, igualmente y sólo por hipótesis, en el potencial destino del habeas data si fuera visualizado a través de la pauta interpretativa determinada en el caso "Fayt", ya que aquél no fue habilitado expresamente por el Congreso Nacional para su debate en la Convención (ver específicamente el art. 3, ' $\mathrm{N}$ ', ibid.), incorporándoselo - para circunvalar la prohibición legal- mediante una mimetización con la acción de amparo ${ }^{39}$.

En cuanto a la fundamentación del fallo, no deja de ser sobreabundante el argumento relativo a la valiosa cotización que el Tribunal adjudica a la admisión-confesión del Congreso acerca de la judiciabilidad de los límites impuestos a la Convención, porque aunque nada hubiese expresado al respecto, es claro que al judiciario igualmente le viene dispensada (e impuesta) la misión de efectuar el contralor de constitucionalidad; sin perjuicio de que ésta haya padecido variadas autodetracciones injustificadas ${ }^{40}$, v.gr., la autoproscripción de la Corte de ingresar de oficio en el análisis de la constitucionalidad de las normas ${ }^{41}$ y la doctrina de las cuestiones políticas no justiciables, de la

-énfasis agregado-, no resultando comprobado que la sanción de la norma constitucional impugnada se halle comprendida en el supuesto excepcional precedentemente recordado (considerando $4 .^{\circ}$ ).

El fallo contó - una vez más - con la importante disidencia del Dr. Luis María BOFFI BOGgero, quien se expidió por la justiciabilidad de la materia sub examine.

39 Para ampliar, puede consultarse BAZŹN, Víctor: «El hábeas data y sus peculiaridades frente al amparon, Revista de Derecho Procesal, n. ${ }^{\circ}$ 4-I [Amparo. Hábeas data. Hábeas corpus], Rubinzal-Culzoni, Santa Fe, Rep. Arg., págs. 215/268, en esp., págs. 255/256.

40 Ver BAZAN, Víctor, por ejemplo en: “Sobre las denominadas cuestiones no judiciables y las detracciones injustificadas al Poder Judicial", en el libro colectivo Temas de Derecho Administrativo III, Foro de Abogados, San Juan, Rep. Arg., 1999, págs. 183/204.

41 Vid. BAZÁN, Víctor, por ejemplo, en «La Corte, la declaración de inconstitucionalidad de oficio y el sendero hacia la superación de una doctrina judicial 
que - precisamente - el caso "Fayt" puede ser considerado un avance, aunque la euforia fue efímera, pues pocos días después de ese caso, el Tribunal resolvió (el 31/08/99) la causa "Guadalupe Hernández, Simón Fermín " ${ }^{42}$, en la que pareciera haberse operado una involución en la materia, ya que frente al amparo articulado por el Vicegobernador de la Provincia de Catamarca (presentación ratificada in totum por el Gobernador) contra el Senado de la Nación para impugnar el ingreso de dos personas a este cuerpo, sustentándose en que no habían sido nominadas por la Asamblea Legislativa provincial, la Corte puntualizó -en mayoría ${ }^{43}$ - que tal temática constituye una facultad privativa de dicha Cámara (considerandos $4 .^{\circ}$ y $5 .^{\circ}$ ) no siendo admisible que los magistrados exorbiten los límites de sus atribuciones y actúen sustituyendo los mecanismos parlamentarios aptos para resolver la controversia (considerando $6 .^{\circ}$ ), aunque intenta matizar su decisión sosteniendo que, ante cuestiones que hacen surgir consideraciones más políticas que legales, el Poder Judicial no debería decidirlas "si no se presenta un atolladero constitucional o una inmovilización del gobierno" ${ }^{44}$ - realzado propio - (considerando $7 . .^{\circ}$ ), con lo que concluyó rechazando el amparo deducido.

inconsistente", El Derecho, 01/10/98, Bs. As., Rep. Arg., págs. 1/6; "Desmitificando la prohibición de ejercer el control de constitucionalidad de oficio en el orden federal argentino", Revista Peruana de Derecho Constitucional, n. ${ }^{\circ}$, Tribunal Constitucional, Lima, Perú, 2000, págs. 301/321; «El control de constitucionalidad de oficio en el ámbito federal argentino y la necesaria superación de una inadecuada concepción jurisdiccional», Foro de Córdoba, Año XI, n. ${ }^{\circ}$ 62, Córdoba, Rep. Arg., 2000, págs. 31/47; “Un debate recurrente: ¿Es sustentable la posición de la Corte Suprema de Justicia de la Nación en el sentido de proscribir el ejercicio jurisdiccional del control de constitucionalidad de oficio?, Entre Abogados, año VII, n. ${ }^{\circ}$, 2000, Foro de Abogados, San Juan, Rep. Arg., págs. 21/35; «Derecho penal tributario, test de razonabilidad y declaración de inconstitucionalidad de oficio", La Ley, t. 2001-C, Bs. As., Rep. Arg., págs. 792/802.

42 Fallos, 322: 1988.

43 La mayoría estuvo conformada por NAZAReno, Moliné O'ConNoR, LoPez Y VAZOUEZ. BOGgIANO lo hizo en voto separado más concurrente. Por su parte, FAYT, Belluscio, Petracchi y Bossert lo hicieron en disidencia, propiciando requerir al Senado de la Nación que, en el plazo de diez días, brinde un informe circunstanciado acerca de los antecedentes y razones que motivaron la conducta asumida en relación con la designación de los senadores por la minoría de la Provincia de Catamarca.

44 Sobre el punto, SAgüEs explica con agudeza que pareciera "que la abstención judicial en las cuestiones políticas tiene un tope de reaseguro sistémico: la judicatura deberia intervenir, pese a todo, si ello es necesario para concluir con una crisis institucional tensiva, de magnitud tal que pueda bloquear la funcionalidad o la persistencia misma del régimen político. Paradojalmente, pues, un con- 
Volviendo al caso "Fayt», y con independencia de la posición que se adopte frente al debate puntual acerca de si se está ante la presencia de una declaración de inconstitucionalidad de una norma constitucional (hipótesis que, presentada fríamente, no resulta sencillo de asimilar) ${ }^{45}$, o sólo ante la declaración de nulidad de una cláusula constitucional introducida inválidamente en la Constitución, es claro que la cuestión discernida y resuelta por la Corte adquiere una gran dosis de conflictividad ya que conduce - cualquiera sea el camino dialéctico que se escoja - a la inaplicación de la norma constitucional (que integra el texto vigente de la Ley Fundamental) con sustento en su pecaminosa gestación e inválida inclusión en el contenido de ésta. Además, ha ejercido control de constitucionalidad lo declaración de nulidad) con alcance genérico, ya que el fallo produce una suerte de congelamiento de la norma y origina un efecto expansivo hacia otros $\operatorname{casos}^{46}$.

flicto de altísimo voltaje político sería apto para transformar una cuestión 'política', en 'justiciable', todo ello, desde luego, según la evaluación discrecional de la propia Corte" (SAGüÉs, Néstor P.: "La jurisprudencia constitucional de la Corte Suprema de Justicia de Argentina (1997-1999)", Anuario Iberoamericano de Justicia Constitucional, Centro de Estudios Políticos y Constitucionales, Madrid, España, 1999, pág. 469).

45 Más allá de la dificultad en captar cuál sería el material de cotejo para determinar, excluyendo las referencias suprapositivas, si una norma es inconstitucional sino la propia Constitución, no se nos escapa la existencia de algún antecedente que en el derecho comparado efectivizara tal descalificación normativa. Asi, el Tribunal Constitucional de Baviera, en 1950, tras admitir la existencia de "principios constitucionales fundamentales que son de naturaleza tan elemental y expresión de un derecho que precede a la Constitución, que el mismo constituyente está vinculado a ellos", se expidió por la factibilidad de estimar nulas las normas constitucionales que, no teniendo dicho rango, dejaran de concordar con los preceptos aludidos. FERNANDEZ SEgADo - de quien tomamos el ejemplo precedentefundamenta la hipótesis al sostener que algunos textos constitucionales establecen una gradación jerárquica de sus propios preceptos; jerarquización que, llevada al extremo, admitiría la probable inconstitucionalidad de las normas constitucionales (FERNÁNDEZ SEGADO, Francisco: El sistema constitucional español, Dykinson, Madrid, España, 1992, págs. 70 y 71).

46 Un elemento de debate del que generalmente se prescinde estriba en que la propia pauta normativa referencial (léase: Ley Nac. $n .^{\circ} 24.309$ ) de cuyo incumplimiento por la Convención extrajo la Corte la nulidad del cuestionado precepto incluido en el texto constitucional (art. 94 , inc. $4 .^{\circ}$, párrafo $3 .^{\circ}-y$, por vía de consecuencia, cláusula transitoria undécima-l, no puede ser considerada - precisamente - un dechado de pulcritud jurídica.

Recuérdense las notorias desprolijidades y violaciones al procedimiento de formación y sanción legislativa durante el proceso que condujo a la declaración de necesidad de la reforma constitucional y que culminó con el dictado de la men- 
Podríamos continuar discurriendo sobre innumerables aristas de la problemática involucrada en la tramitación jurisdiccional de la causa, mas para finalizar, y sólo en orden a atizar el fuego del debate en punto al tema que nos convoca en este trabajo $y$, paralelamente graficar la multiplicidad de facetas del asunto, podríamos inquirir: ¿Cumplía la pretensión del Dr. Fayt, en puridad, los requisitos de la acción declarativa de certeza? ¿Era esta modalidad de acción la adecuada para lograr protección al derecho invocado por el peticionario? La sentencia de 2. ${ }^{a}$ instancia, ¿violó el principio de congruencia? ${ }^{47}$

Como síntesis conclusiva, y aspecto positivo del fallo de la Corte, puede este precedente ser utilizado como importante plafón para ponderar la trascendencia funcional prospectiva de la acción declarativa, potencialmente útil para lograr no ya sólo la inconstitucionalidad de una norma subconstitucional, sino, además, para esterilizar un precepto constitucional.

cionada ley, cuya constitucionalidad, por otro lado (y además de lo estrictamente formal), mereció graves reparos.

Fue así como, por ejemplo y como anunciábamos en la nota 26 , los Sres. Héctor T. Polino y Alfredo P. Bravo - en sus respectivos caracteres de ciudadanos y diputados nacionales - articularon una acción de amparo a efectos de que se declarara la nulidad del proceso legislativo que concluyó en la sanción de la aludida ley, pretensión que se fundaba en la vulneración del trámite de formación y sanción de las leyes establecido por el entonces art. 71 de la Ley Fundamental (actual art. 81). Ambas instancias de mérito rechazaron la acción y, ante tal situación, sólo el diputado Polino interpuso el recurso extraordinario federal, que fue desestimado por la Corte (en actitud mucho menos progresista que la evidenciada en el caso "Fayt»), en fecha 07/04/94, en virtud de la carencia de legitimación del recurrente, tanto como diputado (dada la falta de sustento del interés propio que aludía el impetrante - considerando $6 .^{\circ}-1$ cuanto como ciudadano (considerandos $2 .^{\circ}$ a 5. ${ }^{\circ}$ ) [vid. La Ley, t. 1994-C, Bs. As., Rep. Arg., págs. 291 y ss.]. En sentido análogo, puede consultarse lo resuelto en el caso "Romero Feris" (Fallos, 317: 711).

47 Hernandez ha criticado el fallo con toda dureza. Su posición puede sintetizarse del siguiente modo: el pronunciamiento significa el quebrantamiento de la Constitución; denota la politización de la justicia y la judicialización de la política; trasunta un sentido corporativo; y consuma una grave lesión a los sistemas republicano y democrático. Por último, insta a la defensa de la Constitución no sin antes puntualizar que el fallo ha afectado las bases mismas de nuestro Estado de Derecho al disponer la revisión y la nulidad de un acto del poder constituyente federal, lo que - a su criterio - plantea la necesidad de afirmar los principios y límites del control de constitucionalidad para que en el futuro no sólo se corrija tan erróneo precedente sino para que no se vuelva a repetir alguno similar (HERNÁNDEZ [H.], ANTONIO M.: El caso 'Fayt' y sus implicancias constitucionales, Academia Nacional de Derecho y Ciencias Sociales de Córdoba, Córdoba, Rep. Arg., 2001, págs. 86/91). 


\section{3. «Palópoli, Hugo Daniel c/ Provincia de Buenos Aires s/ acción declarativa»}

En esta causa, resuelta el $03 / 02 / 2000^{48}$, la Corte hizo lugar a la acción declarativa articulada, encaminada a obtener una declaración de certeza respecto del alcance, límites y modalidad del Decreto Nac. n. ${ }^{\circ} 2.293 / 92$ y a que se dilucide el estado de incertidumbre que el actor sostenía le creaba la exigencia de la Caja de Seguridad de Médicos Veterinarios de efectuar los aportes jubilatorios previstos por la Ley Prov. $n .^{\circ} 10.476$; esto último, en tanto se le imponía la realización de aportes por el lapso en que, sin ejercer actividad profesional independiente, se desempeñó únicamente en la Corporación del Mercado Central de Bs. As., con la obligación consiguiente de aportar a la ex Caja de Previsión Social para el Personal del Estado y Servicios Públicos, lo que contrariaría el art. 14 bis de la C.N.

Como dijimos, el Tribunal admitió la demanda (considerando, además, que la petición encuadraba en el art. 322 del C.P.C.C.N.) y declaró la inconstitucionalidad de los arts. 5 y 8 de la Ley n. ${ }^{\circ} 10.746$ de la Provincia de Buenos Aires, en tanto su aplicación al actor (en el lapso temporal determinado en la sentencia: del 22/07/91 al 20/11/92) implicaría una superposición de aportes fulminada por la Ley Fundamental (ver considerando $7 .^{\circ}$ ).

\section{SÍNTESIS DE LA DOCTRINA DE LOS FALLOS RELACIONADOS}

En orden a perfilar un panorama abarcativo de la evolución del criterio de la Corte respecto de la acción declarativa de inconstitucionalidad en el orden federal, pasamos a sintetizar algunas de las partes sustanciales que, de dichas sentencias, resultan inherentes al problema en estudio:

1. «Provincia de Santiago del Estero v. Nación Argentina»

Con un interesante y valioso desapego por el rigorismo formal, la Corte prescindió del nomen iuris dado por la accionante a su pre-

Fallos, 323: 19. 
tensión (articulada primigeniamente como amparo), recanalizándola para subsumirla en el radio de cobertura de la acción declarativa regulada en el art. 322 del C.P.C.C.N., a la que estimó como un recaudo apto para evitar el eventual perjuicio denunciado por la actora que planteaba ante los estrados del Tribunal una relación jurídica discutida o incierta, evidenciándose la convergencia de un interés real y concreto susceptible de protección legal actual. Igual temperamento adoptó - como vimos-, años más tarde, en «Provincia de Río Negro c/ Nación Argentina».

\section{2. "Lorenzo"}

La Corte sostuvo que no puede afirmarse que en el orden nacional no exista la acción declarativa de inconstitucionalidad; sino que, para que ella sea viable, debe desenvolverse en verdaderos "caso" o "causa" contenciosos, en los que se persiga in concreto la determinación del derecho debatido entre partes adversas; es decir, acciones determinativas de derechos de base constitucional cuya titularidad alegue el actor y que estén dirigidas a prevenir o impedir lesiones a tales derechos.

\section{3. «Klein»}

El Tribunal declaró que su pronunciamiento sería inoficioso, pues no habría ningún derecho debatido a determinar entre las partes, sin perjuicio de lo cual, reafirmó el reconocimiento de la acción de mera certeza en materia constitucional, siempre que se configuren sus requisitos de admisibilidad.

\section{4. «Fábrica Argentina de Calderas»}

El Tribunal introdujo, y no precisamente en forma tangencial, el control de constitucionalidad en el marco de una acción que involucraba una petición de certeza, aunque -como anunciábamos-en autos no se había articulado formalmente una acción declarativa, por lo que - para emitir su fallo- la Corte prescindió del nomen iuris proporcionado por la peticionante. 


\section{5. "Gomer"}

Puede ser catalogado como el primer precedente en el que la Corte construye su razonamiento sobre la base de admitir la posibilidad de ejercer control de constitucionalidad a través de la acción declarativa. Es que abre la parte considerativa del resolutorio afirmando contundentemente que «de conformidad con la jurisprudencia del Tribunal existe en el orden nacional la acción declarativa de inconstitucionalidad y ella puede ser instaurada directamente ante esta Corte cuando se dan los requisitos que determinen su intervención en instancia originaria» -énfasis propio-.

\section{6. «Newland»}

El Tribunal (ya con diferente composición) mudó un restrictivo y censurable criterio jurisprudencial sentado in re "Bridas» consistente en que, dado el carácter subsidiario de la pretensión declarativa, ésta quedaba relegada por otras vías legales - igualmente aptas - para efectuar planteos relativos a cuestiones tributarias, además de que debia cumplirse con la regla solve et repete de modo previo a acudir a la justicia y, luego y en su caso, intentar la restitución de lo oblado.

\section{7. "Asociación Civil Escuela Escocesa San Andrés"}

En dirección convergente a "Newland», mas referido concretamente a la petición de concesión de una medida cautelar en una acción meramente declarativa, planteada ante la Corte y fundada en la pretendida inconstitucionalidad de la Ley Prov. (de Bs. As.) n. ${ }^{\circ}$ 10.427 en cuanto entrañaría una violación directa a la Ley Nac. $n .^{\circ}$ 18.037 y a la C.N., el máximo órgano jurisdiccional nacional entendió que existía "causa" y que se encontraban satisfechos los requisitos de admisibilidad del art. 322 del C.P.C.C.N., por lo que - aun cuando rechazó la cautelar impetrada - afirmó su competencia para entender en el proceso.

\section{8. "AGUEeRA c/ Provincia de Bs. As."}

Reafirmó la analogía existente entre el amparo y la acción declarativa, manifestando que el pedido de declaración de inconstituciona- 
lidad de una norma importa el ejercicio de una acción directa de inconstitucionalidad, de aquéllas que explícitamente ha admitido como medio idóneo - ya sea bajo la forma del amparo, la acción de mera certeza o el juicio sumario en materia constitucional - para prevenir o impedir las lesiones de derechos de base constitucional. Además, es importante advèrtir que consideró a la acción declarativa de inconstitucionalidad como medio idóneo, tanto como el amparo, para dar protección jurisdiccional a los derechos de incidencia colectiva, sosteniendo que el hecho de que la demanda se haya planteado sobre la base del art. 322 del C.P.C.C.N. no resultaba obstáculo para dar resguardo a tal tipología de derechos, ya que ella posee una finalidad preventiva y no requiere la existencia de daño consumado.

\section{9. "Provincia de Río Negro»}

En sintonía con el fallo relatado en forma inmediatamente precedente, el Tribunal expresó que la acción declarativa de inconstitucionalidad, al igual que el amparo, posee una finalidad preventiva $y$ no requiere la existencia de daño consumado en resguardo de los derechos, razón por la que consideró viable prescindir válidamente del nomen iuris empleado por la peticionaria y atender a la real sustancia de la solicitud por medio del ejercicio de la acción declarativa regulada en el art. 322 del C.P.C.C.N.

\section{0. «Iribarren, Casiano Rafael c/ Provincia de Santa Fe»}

En la causa de mención, la Corte, en el marco de una acción declarativa de certeza planteada en instancia originaria, declaró la inconstitucionalidad del art. 88 de la Constitución de la Provincia de Santa $\mathrm{Fe}$, que establece la pérdida de la inamovilidad de los jueces a los 65 años de edad si se encuentran en condiciones de acogerse a la jubilación ordinaria, argumentando que se sometía a tales magistrados sine die a permanecer en la función, con un carácter precario, sujetando ese estado al exclusivo arbitrio del Poder Ejecutivo.

\section{1. «Fayt»}

El caso "Fayt" debe ser incluido en este repaso jurisprudencial de la evolución de la acción declarativa de inconstitucionalidad en la 
percepción de la Corte, por cuanto si bien formalmente concluyó con la declaración de nulidad de la norma en crisis (nada más y nada menos que un precepto constitucional, concretamente, de la reforma introducida en el art. 99 , inc. $44^{\circ}$, párrafo $3 .^{\circ}$ de la C.N. - en la disposición transitoria undécima - al art. $110 \mathrm{ibid}$.), en puridad y en el marco de una acción declarativa, ejerció control de constitucionalidad sobre la labor del poder constituyente derivado y "congeló" la norma impugnada, inhibiendo su futura aplicación.

\section{2. «Palópoli»}

En esta causa, la Corte admitió la demanda, considerando que la petición encuadraba en el art. 322 del C.P.C.C.N., y declaró la inconstitucionalidad de los arts. 5 y 8 de la Ley $n .^{\circ} 10.746$ de la Provincia de Buenos Aires, en tanto su aplicación al actor (en el lapso temporal que la sentencia determina) implicaría una superposición de aportes jubilatorios contraria a la C.N.

\section{UN RECORRIDO COMPARATIVO POR EL DERECHO PÚBLICO PROVINCIAL Y EL DE LA CIUDAD AUTÓNOMA DE BUENOS AIRES}

A continuación, acometeremos una relación de las normas constitucionales provinciales que guardan alguna conexión con el objeto de este estudio, intimamente convencidos de la importancia de conocer y - por qué no- usufructuar las experiencias - positivas y negativas - de los Estados provinciales.

Luego de ello, efectuaremos una breve vinculación comparativa de los aspectos comunes y las diferencias perceptibles a partir de las respectivas regulaciones constitucionales.

\section{Repaso de las normativas constitucionales}

Permítasenos efectuar dos advertencias preliminares: la primera, simplemente para expresar que la presentación se efectuará siguiendo el orden alfabético del nombre de cada provincia; la segunda, para manifestar que se incluirá en el señalamiento a la Ciudad Autónoma de Buenos Aires que, aun cuando no se trate stricto sensu 
de una provincia, posee status constitucional (vid art. 129 de la C.N.) por lo que resulta importante reseñar su normativa al respecto, la que - por lo demás - ofrece ciertas particularidades dignas de mención.

A continuación, daremos lugar al detalle anunciado:

\section{a) Constitución de la Provincia de Buenos Aires}

Dentro del marco de las atribuciones de la Suprema Corte de Justicia, el art. 161 , inc. $1 .^{\circ}$, dispone que ella ejerce la jurisdicción originaria y de apelación para conocer y resolver acerca de la constitucionalidad o inconstitucionalidad de leyes, decretos, ordenanzas o reglamentos que estatuyan sobre materia regida por la Constitución y se controvierta por parte interesada.

En lo que hace específicamente a la acción de inconstitucionalidad dentro de la competencia originaria (y en única instancia) de la Suprema Corte, ella se encuentra diseñada como un proceso especial, y discurre reglamentada en los arts. 683 a 688 del Código Procesal en lo Civil y Comercial local.

La acción debe ser articulada, por quien ostente un interés directo y particular, en un plazo de 30 días contado desde que el precepto objetado afecte concretamente los derechos patrimoniales del accionante (art. 684, párrafo $1 .^{\circ}$, del C.P.C.C.). Producida la caducidad de dicho parámetro temporal, se considerará extinguida la competencia originaria de la Suprema Corte, aunque queda al interesado la posibilidad de plantear la cuestión ante la jurisdicción ordinaria en defensa de los derechos patrimoniales que estime afectados - párrafo $2 .^{\circ}$, art. 684 , ibid- (y así, escalando instancias, arribar al máximo órgano jurisdiccional provincial por la vía recursiva).

Por su parte, cabe dejar en claro que aquel plazo no se aplica cuando se cuestionan normas (leyes, decretos, ordenanzas o reglamentos) de carácter institucional o que afecten derechos de la personalidad no patrimoniales o si la acción es ejercitada preventivamente, esto es, cuando la cláusula impugnada aún no se hubiera aplicado al peticionario (art. 685 ibid.).

Articulada la demanda, ésta se sustancia - según correspondacon el Asesor de Gobierno (cuando el acto objetado provenga de los Poderes Legislativo o Ejecutivo), los representantes legales de las municipalidades o los titulares de los organismos involucrados (cuando las normas dimanen de tales entidades) -art. 686 ibid.-. 
Contestado el traslado o vencido el plazo acordado para hacerlo (15 dias), deben producirse las pruebas ofrecidas; cumplido lo cual, y previa vista al Procurador General de la Suprema Corte, se dictará la providencia de autos (art. $687 \mathrm{del}$ mismo cuerpo legal).

Si la sentencia es estimatoria, el Tribunal deberá hacer la correspondiente declaración sobre los puntos discutidos (art. 688 ibid.). Los efectos del pronunciamiento se limitan exclusivamente al proceso $y$ sólo vinculan a las partes intervinientes, es decir, que el precepto declarado inconstitucional no pierde vigencia, por lo que continúa siendo operativo, sin perjuicio de que recaigan otros decisorios semejantes en los casos concretos que en adelante se sometan al Tribunal49.

\section{b) Constitución de la Ciudad Autónoma de Buenos Aires}

La organización del control de constitucionalidad en el esquema de la Ciudad Autónoma de Buenos Aires ofrece particularidades dignas de, al menos, una mínima mención.

Es que en el ámbito porteño coexisten dos sistemas de contralor: uno difuso e in concreto (cfr. artículos constitucionales 1, 106 y 113 - salvo el inc. $2 .^{\circ}$ de esta última norma-1, deferido a todos los órganos jurisdiccionales y que, por vía del recurso de inconstitucionalidad, puede llegar al Tribunal Superior de Justicia [en adelante: T.S.J.] en todos los casos que versen sobre la interpretación o aplicación de normas contenidas en las Constituciones Nacional o local (ver art. 113, inc. $\left.3 .^{\circ}\right)$; y, por otra parte, uno concentrado e in abstracto, titularizado exclusivamente por el T.S.J. (art. 113, inc. $2^{\circ} \%$.

En cuanto al concentrado, cabe recalcar que en virtud de la cláusula citada en último término, el Tribunal Superior conoce en instancia originaria y exclusiva en las acciones declarativas contra la validez de leyes, decretos y cualquier otra norma de carácter general emanada de las autoridades de la Ciudad, contrarias a la Carta Magna Nacional o a la local.

Es interesante tener en cuenta que en la hipótesis sub discussio la declaración de inconstitucionalidad tiene efecto derogatorio de la

49 Cfr. Morello, Augusto M.; Sosa, Gualberto L.; Berizonce, Roberto O. ,Y Tessone, Alberto: Códigos Procesales en lo Civily Comercial de la Provincia de Buenos Aires y de la Nación, t. VII-B, 2. ${ }^{a}$ ed. reelab. y ampl., Libr. Edit. Platense - Abeledo-Perrot, Bs. As., Rep. Arg., pág. 463. 
norma en cuestión, salvo que ésta se trate de una ley y la Legislatura la ratifique, por mayoría de los dos tercios de los miembros presentes, dentro de los 3 meses de la sentencia declarativa. Dicha ratificación no altera los efectos que para el caso concreto produzca la declaración judicial de inconstitucionalidad ni impide el posterior control difuso de constitucionalidad a cargo de todos los jueces y del propio Tribunal Superior. Sobre el punto, Sagüés manifiesta que la del art. 113 , inc. $2^{\circ}$, entraña una peculiar pero interesante vía de control legislativo-judicial de constitucionalidad ${ }^{50}$.

Ya en punto a la cuestión específica que abordamos en el presente trabajo (acción declarativa de inconstitucionalidad), el propio Tribunal califica al control de constitucionalidad establecido en el art. 113, inc. $2^{\circ}$, de la Ciudad Autónoma de Buenos Aires, que debe ejercer exclusiva y originariamente, como concentrado y abstracto, puntualizando que no puede ser confundido con el difuso reconocido a todos los jueces, orientado al dictado de sentencias en las que se valoran situaciones jurídicas individualizadas ${ }^{51}$. En otras palabras, a través de la acción declarativa de inconstitucionalidad se vehicularía un cuestionamiento abstracto de una norma general (art. constitucional art. 113 , inc. $2 .^{\circ}$ ).

\section{c) Constitución de la Provincia de Córdoba}

El art. 165 , inc. $1 .^{\circ}$, ap. ' $a$ ', dispone que el Tribunal Superior de Justicia recepta competencia para conocer y resolver originaria y exclusivamente, en pleno, de las acciones declarativas de inconstitucionalidad de leyes, decretos, reglamentos, resoluciones, Cartas Orgánicas y ordenanzas, que estatuyan sobre materia regida por la Constitución provincial, y se controviertan en caso concreto por parte interesada 52 .

50 SAgüEs, Néstor.P.: Constitución de la Ciudad Autónoma de Buenos Aires, Introducción, Astrea, Bs. As., Rep. Arg., 1996, pág. 64.

51 Causa SAO 31/99, «Massalin Particulares S.A. c/ Gobierno de la Ciudad de Buenos Aires s/ acción declarativa de inconstitucionalidad», del 05/05/99.

52 En los arts. 413 y 418 del Código de Procedimientos en lo Civil local se encuentran los lineamientos a observar por la acción declarativa de certeza. En la primera de dichas normas se especifica quién puede entablar la acción laquél que ostente un interés legítimo, a fin de hacer cesar un estado de incertidumbre, que le causa perjuicio - aun sin lesión actual-sobre la existencia, alcance o modali- 
En este breve señalamiento normativo cabe recordar a la Ley Orgánica del Poder Judicial $n .^{\circ} 8.435$, en cuyo art. 11, inc. 1 , se dispone: "Competencia. El Tribunal Superior de Justicia tendrá la siguiente competencia: 1. Conocer y resolver originaria y exclusivamente, en pleno: a) De las acciones declarativas de inconstitucionalidad de las Leyes, Decretos, Reglamentos, Resoluciones, Cartas Orgánicas y Ordenanzas, que estatuyan sobre materia regida por la Constitución, y se controvierta en caso concreto y por parte interesada".

Al comentar el instituto, Robledo recuerda que aquél ostenta carácter excepcional por implicar un control jurisdiccional directo, objeto de competencia originaria y exclusiva del Tribunal, requiriendo las siguientes condiciones de admisibilidad: "caso concreto" y "parte interesada" 53 . El autor citado entiende que "caso concreto" equivale a un "conflicto de intereses" que se produce entre sujetos o partes de una relación jurídica sustancial ${ }^{54}$; de su lado, la expresión "parte interesada» exige la acreditación del interés del reclamante, lo que importa que éste sea titular de un derecho subjetivo o de un interés legítimo amenazado y que se encuentre legitimado para deducir la acción declarativa de inconstitucionalidad 55 .

\section{d) Constitución de la Provincia del Chaco}

Dicha Constitución, en su art. 163 , inc. $1 .^{\circ}$, ap. ' $a$ ', determina que, como atribución judicial, el Superior Tribunal de Justicia ejerce jurisdicción ordinaria y exclusiva en las demandas por inconstitucionalidad de leyes, decretos, ordenanzas, reglamentos o resoluciones, que se promuevan directamente por vía de acción ${ }^{56}$.

dades de una relación jurídica); en el segundo de los preceptos nombrados, por su parte, se regulan las pautas atinentes a la canalización procesal de dicha acción, por medio del trámite del juicio abreviado.

53 RoBledo, Federico J.: "Acción declarativa de inconstitucionalidad", Boletín Informativo de la Asociación Argentina de Derecho Constitucional, Año XVI, $\mathrm{n}{ }^{\circ}$ 172, agosto de 2000, Bs. As., Rep. Arg., pág. 6.

54 ídem.

55 Cfr. Tribunal Superior de Justicia Córdoba, en pleno, 18/12/97, A.l.392: "Gobbato, Santiago Arnaldo y otros c/ Provincia de Córdoba - Acción de Inconstitucionalidad", Semanario Jurídico, Fallos y Doctrina, n. ${ }^{\circ} 1.193,04 / 06 / 98$, Córdoba, Rep. Arg., págs. 604 y ss.; mencionado por RoBledo, Federico J., op. cit., págs. 6/7.

56 Una norma de similar calibre contiene la Constitución de Formosa, al determinar que el Superior Tribunal de Justicia ejerce la jurisdicción ordinaria y de 
Por el artículo constitucional 174 se establece que el Fiscal de Estado tendrá la obligación de demandar la inconstitucionalidad o la nulidad de leyes, decretos, resoluciones o actos públicos contrarios a las prescripciones de la Constitución local, que en cualquier forma perjudiquen los derechos e intereses provinciales.

Por su parte, el art. 9, párrafo $2 .^{\circ}$, ibid., prevé que la inconstitucionalidad declarada por el mencionado Tribunal produce la caducidad de la ley, decreto, ordenanza o disposición en la parte afectada por aquella declaración.

\section{e) Constitución de la Provincia de Chubut}

En cuanto a las atribuciones competenciales del Superior Tribunal de Justicia, el art. 179 , inc. $1 .^{\circ}$, ap. 1 , determina que éste conoce y resuelve originaria y exclusivamente, en pleno, de las acciones declarativas de inconstitucionalidad de leyes, decretos, reglamentos, resoluciones, cartas orgánicas y ordenanzas municipales, que estatuyan sobre materia regida por la Constitución provincial y se controviertan en caso concreto por parte interesada.

Por virtud del art. 215, párrafo $2 .^{\circ}$, ibid., el Fiscal de Estado puede recurrir ante la jurisdicción que corresponda, de toda ley, decreto, contrato o resolución contrarios a la Constitución provincial o que en cualquier forma contraríen intereses patrimoniales del Estado.

Es importante poner de relieve que, cuando el Superior Tribunal declara por dos veces consecutivas o tres alternadas la inconstitucionalidad de una norma legal, ésta deja de tener vigencia a partir del día siguiente a la publicación oficial de la sentencia definitiva (art. 175 ibid.).

\section{f) Constitución de la Provincia de Entre Ríos}

Como atribución en materia judicial, y de conformidad con las normas que establezcan las leyes de la materia, el Superior Tribunal

apelación para conocer y resolver acerca de la constitucionalidad de leyes, decretos, ordenanzas o reglamentos que estatuyan sobre materia regida por la Constitución provincial y se controviertan por parte interesada (art. 167, inc. $2^{\circ}$ ). 
de Justicia de tal provincia ejercerá jurisdicción originaria y exclusiva en las gestiones acerca de la constitucionalidad de leyes, decretos, ordenanzas, resoluciones o reglamentos que estatuyan en materia regida por la Constitución local, y que se promuevan directamente por vía de acción ante dicho órgano jurisdiccional (art. 167, inc. 1.․ ap. 'c').

\section{g) Constitución de la Provincia de Jujuy}

Como norma genérica, el art. 148 de la Constitución local prevé que al Poder Judicial le corresponde resolver en definitiva sobre la constitucionalidad de las leyes, decretos, ordenanzas, reglamentos o resoluciones que estatuyan sobre materia regida por dicha Constitución.

El artículo constitucional 164 , inc. $1 .^{\circ}$, edicta que el Superior Tribunal de Justicia conoce y resuelve originaria y exclusivamente en las acciones por inconstitucionalidad de leyes, decretos, ordenanzas, reglamentos o resoluciones.

Por el art. 198, inc. $4 .^{\circ}$, ibid., se asigna al Fiscal de Estado la función de demandar ante cualquier fuero y jurisdicción cuando los actos de la Nación, la Provincia o los Municipios fueren contrarios a la Constitución y a la ley.

Para finalizar esta reseña, corresponde indicar que el 29/12/87 se sancionó la Ley Prov. $n .^{\circ} 4.346$ (promulgada el 19/01/88 y publicada en junio de ese año), modificada por las Leyes Provs. n.os. 4.848 (del 24/10/95) y 5.052 (del 05/05/98), arco normativo que diagrama la "Reglamentación de la acción y el recurso de inconstitucionalidad".

En cuanto a la legitimación para articular la acción de inconstitucionalidad, el art. 1 de la Ley Prov. $n .^{\circ} 4.346$, preceptúa que ella podrá ser ejercida por quien tenga un interés legítimo debidamente justificado. Por su parte, y ya con respecto a los alcances de la sentencia declarativa de inconstitucionalidad, el art. 7, ap. 3, de la mencionada ley, precisa que "la norma cuestionada no podrá volver a ser aplicada, si se tratare de una disposición de carácter general, salvo que la inconstitucionalidad no proviniere de la norma, sino de su errónea interpretación o defectuosa aplicación". Sobre el punto se ha sostenido que la cláusula legal aludida en referida término otorga efectos. derogatorios a la sentencia que acoge favorablemente la pretensión 
de inconstitucionalidad, en tanto aluda a una norma que contenga una disposición de carácter general ${ }^{57}$.

\section{h) Constitución de la Provincia de La Pampa}

Por el art. 97, inc. $1 .^{\circ}$, el Superior Tribunal de Justicia recepta, en el marco de las atribuciones y deberes que le vienen impuestos constitucionalmente, la de ejercer la jurisdicción originaria y de apelación para resolver cuestiones controvertidas por parte interesada, referentes a la inconstitucionalidad de leyes, decretos, ordenanzas, edictos, resoluciones o reglamentos que estatuyan sobre materias regidas por la Constitución provincial.

En función del art. 101, párrafo 2..$^{\circ}$ ibid., el Fiscal de Estado recepta "personeria" para demandar la nulidad e inconstitucionalidad de una ley, decreto, reglamento, contrato o resolución que puedan perjudicar los intereses fiscales de la provincia.

\section{i) Constitución de la Provincia de La Rioja}

En el art. 141 , inc. $10^{\circ}$, se acuerda al Tribunal Superior el ejercicio de competencia originaria y exclusiva en las demandas que se promuevan directamente por via de acción por inconstitucionalidad de leyes, decretos, ordenanzas y reglamentos.

Sobre la base del artículo constitucional 145, el Fiscal de Estado ostenta "personería" para demandar la nulidad e inconstitucionalidad de leyes, decretos, reglamentos, contratos o resoluciones en el solo interés de la ley o en defensa de intereses fiscales de la provincia.

57 GrisettI, Ricardo A.; Kamada, Luis E.; Parera Gaviña, Ignacio M.; CabaLLero, Alejandra M. L.; López IrIARTE, Constanza, y MonTES, Amalia: «Acción declarativa de inconstitucionalidad: Legitimación y alcances de la sentencia o el problema de sus límites subjetivos y objetivos", ponencia presentada al "XXI Congreso Nacional de Derecho Procesal", Comisión: "Proceso Constitucional y Administrativo", Subcomisión 1: "Acción declarativa de inconstitucionalidad", Universidad Católica de Cuyo, San Juan, Rep. Arg., 13 al 16 de junio de 2001, pág. 864. 


\section{j) Constitución de la Provincia de Mendoza}

La Constitución mendocina establece en su art. 144 , inc. $3 .^{\circ}$, que la Suprema Corte de Justicia local ejerce jurisdicción originaria y de apelación para conocer y resolver sobre la constitucionalidad o inconstitucionalidad de leyes, decretos, ordenanzas, resoluciones o reglamentos que estatuyan sobre materia regida por la Ley Fundamental provincial y se controviertan por parte interesada.

Por su parte, al Fiscal de Estado se le acuerda "personería» para demandar ante la Suprema Corte y demás Tribunales provinciales, la nulidad de toda ley, decreto, contrato o resolución, contrarios a las prescripciones constitucionales locales, o que en cualquier forma perjudiquen los intereses fiscales de la provincia (art. 177, párrafo $2 .^{\circ}$, ibid.).

Kemelmajer de Carlucci apunta que los efectos de la acción dependen de la naturaleza de los actos atacados; así, si se trata de una cuestión que sólo atiende al interés particular, es válida para el caso (concreto), mientras que si están comprometidos intereses públicos, sus efectos son generales ${ }^{58}$. En tal sentido, cita un fallos (del 04/05/89, in re "Unión de Centro Democrático y otros c/Provincia de Mendoza") en el que la Sala $1 .^{a}$ de la Suprema Corte de Justicia local entendió que "cuando la acción de inconstitucionalidad ha sido interpuesta por un sujeto particular pero teniendo a la base un derecho subjetivo público y están en juego intereses públicos tiene los mismos efectos que si hubiese sido deducida por el Sr. Fiscal de Estado (art. 172, $2 .^{\circ}$ párrafo de la Constitución de Mendoza)" ${ }^{59}$.

\section{k) Constitución de la Provincia de Misiones}

El Superior Tribunal de Justicia recibe en materia judicial la atribución de ejercer jurisdicción originaria y por apelación para conocer y resolver sobre la constitucionalidad de las leyes, decretos, ordenanzas, resoluciones o reglamentos que estatuyan sobre materia reglada por la Constitución local (cfr. art. 145, inc. 1.\%).

58 Kemelmajer de Carluccl, Aida R.: «Atribuciones de los Superiores Tribunales de Justicia», en el volumen colectivo: Derecho Público Provincial, t. II, Instituto Argentino de Estudios Constitucionales y Politicos, Depalma (distr.), Mendoza, Rep. Arg., 1991, pág. 495.

59 Idem. 
De modo similar a algunas de las previsiones constitucionales reseñadas anteriormente, el Fiscal de Estado tiene "personería" para defender la nulidad o inconstitucionalidad de la ley, decreto, reglamento, contrato o resolución que puedan perjudicar los intereses fiscales (art. 128, in fine, ibid.).

\section{1) Constitución de la Provincia de Neuquén}

Por medio del art. 170, inc. ' $a$ ', se ha discernido al Tribunal Superior de Justicia el ejercicio de la jurisdicción originaria y exclusiva para conocer y resolver en las cuestiones que se promuevan directamente ante el mismo, en caso concreto y por vía de acción sobre constitucionalidad o inconstitucionalidad de las leyes, decretos, resoluciones, ordenanzas y reglamentos que estatuyan sobre materia regida por la Constitución provincial.

Por su parte, el artículo constitucional 136 edicta que el Fiscal de Estado ostenta "personería» para demandar ante el Superior Tribunal y demás Tribunales provinciales, la nulidad de toda ley, decreto, contrato o resolución contrarios a las imposiciones de la Constitución o que en cualquier forma perjudiquen los intereses fiscales de la provincia.

Por último, es de resaltar que el párrafo $2 .^{\circ}$ del art. 30 ibid., preceptúa que la inconstitucionalidad declarada por el Tribunal Superior de Justicia, en ejercicio de su jurisdicción originaria, produce la caducidad de la ley, ordenanza, decreto $u$ orden en la parte afectada por aquella declaración.

\section{m) Constitución de la Provincia de Río Negro}

El art. 207 (titulado: Competencia), inc. $1 .^{\circ}$, establece como atribución del Superior Tribunal de Justicia el ejercicio de la jurisdicción originaria y de apelación para conocer y resolver acerca de la constitucionalidad o inconstitucionalidad de las normas que estatuyan sobre materias regidas por la Constitución provincial y que se controviertan por parte interesada. Añade la norma que, en la vía originaria, podrá promoverse la acción sin lesión actual.

En el art. 208 ibid., prevé que cuando el Superior Tribunal de Justicia, en juicio contencioso, declara por unanimidad y por tercera vez 
la inconstitucionalidad de un precepto materia de litigio contenido en una norma provincial o múnicipal puede, en resolución expresa dictada por separado, declarar abrogada la vigencia de aquella norma, que deja de ser obligatoria - deducimos - a partir de la publicación oficial del temperamento derogatorio adoptado por el Tribunal (párrafo $1 . .^{\circ}$.

A su hora, el párrafo $2 .^{\circ}$ del citado art. 208, dispone que si la regla en cuestión fuere una ley, el Superior Tribunal debe dirigirse a la Legislatura a fin de que proceda a eliminar su oposición con la norma superior. Si el órgano legisferante no adopta dicha decisión en el plazo de 6 meses de recibida la comunicación del Tribunal, éste ordena la publicación del fallo y se produce la derogación automática de la norma tildada de inconstitucional.

\section{n) Constitución de la Provincia de Salta}

A la Corte de Justicia local le compete conocer y decidir en forma originaria las acciones sobre inconstitucionalidad de leyes, decretos, ordenanzas, reglamentos o resoluciones que estatuyan sobre materias regidas por la Constitución provincial (cfr. art. 153.II.'a').

Por su parte, el art. 149 ibid prevé que, a requerimiento del Gobernador, el Fiscal de Estado se halla legitimado para demandar la inconstitucionalidad y nulidad de toda ley, decreto, ordenanza, contrato, resolución o acto de cualquier autoridad de la provincia que sean contrarios a las prescripciones de la Constitución local.

\section{n) Constitución de la Provincia de San Luis}

El art. 213 , inc. $1 .^{\circ}$, estipula que al Superior Tribunal corresponde ejercer la jurisdicción originaria y de apelación para conocer y resolver acerca de la constitucionalidad e inconstitucionalidad de las leyes, decretos y ordenanzas que estatuyan sobre materia regida por la Constitución local y se controvierta por parte interesada.

A su turno, el artículo constitucional 237 , inc. $3 .^{\circ}$, pauta que el Fiscal de Estado - como encargado de defender los intereses de la provincia -, acciona ante quien corresponda para que se declare la inconstitucionalidad de toda ley, decreto, carta municipal, ordenanza, resolución o acto administrativo. 
Por último, cabe destacar que el art. 10, in fine, ibid., ordena que la inconstitucionalidad declarada por el Superior Tribunal de Justicia debe ser comunicada formal y fehacientemente a los poderes públicos correspondientes, a los fines de sus modificaciones y adaptaciones al orden jurídico vigente.

\section{o) Constitución de la Provincia de San Juan}

El art. 208, inc. $3 .^{\circ}$, ap. A), proporciona base normativa para entender institucionalizada la acción directa de inconstitucionalidad articulable ante el Juez de $1 .^{a}$ instancia, pues aquel precepto -en el tramo pertinente - le acuerda a la Corte de Justicia la atribución jurisdiccional de conocer y resolver en grado de apelación uen las causas sobre inconstitucionalidad de leyes, decretos, ordenanzas, reglamentos $y$ resoluciones promovidas ante los tribunales inferiores".

La Constitución sanjuanina acuerda carácter "obligatorio" (para los órganos jurisdiccionales inferiores) a la jurisprudencia plenaria producida por el máximo tribunal provincial (art. constitucional 209). En otro tramo de la normativa constitucional de dicha provincia, se ha establecido que «la inconstitucionalidad declarada por la Corte de Justicia de la Provincia debe ser comunicada formal y fehacientemente a los poderes públicos correspondientes, a los fines de sus modificaciones y adaptaciones al orden jurídico vigente" (párrafo in fine del art. 11).

Además, y en casos puntuales (cuando la petición de inconstitucionalidad viene planteada por el Fiscal de Estado) se confiere al máximo tribunal local jurisdicción originaria y exclusiva para conocer en las demandas por inconstitucionalidad de leyes, decretos, ordenanzas, reglamentos o resoluciones que se promuevan directamente por vía de acción y en caso concreto (Cfr. arts. 208 , inc. $2 .^{\circ}$, y 265 de la Ley Fundamental provincial). Debe notarse que, no ya por vía constitucional sino legislativa ${ }^{60}$, se ha conferido idéntica facultad que la acor-

60 Ello fue fijado en la Ley Prov. n. ${ }^{\circ} 5.854$-Orgánica de Tribunales-, concretamente en el art. 94 , inc. $10 .^{\circ}$ (t.o. Ley Prov. $n .^{\circ} 5.905$ ). Actualmente rige la Ley Prov. n. ${ }^{\circ} 7.014$ (B.O. del 09/03/2000), específica para el Ministerio Público, que además de derogar los arts. 94 a 115 de la Ley Prov. $n .^{\circ} 5.854$ y modificatorias (ver art. 48), ha establecido en su art. 11, inc. 19, la facultad del Fiscal General de la Corte de Justicia (cabeza de dicho Ministerio) para peticionar ante la Corte (de conformidad con el artículo constitucional 208 , inc. $\left.22^{\circ}\right)$ la declaración de inconstitucio- 
dada al Fiscal de Estado, al Fiscal General de la Corte - cabeza del Ministerio Público, órgano este último que integra el Poder Judicial(art. 202 de la Constitución local).

\section{p) Constitución de la Provincia de Santa Cruz}

La Norma Fundamental santacruceña dispone que al Superior Tribunal de Justicia corresponde ejercer la jurisdicción originaria y de apelación para conocer y resolver acerca de la constitucionalidad de las leyes, decretos, resoluciones, reglamentos y ordenanzas que estatuyan sobre materia regida por la Constitución provincial y se controviertan por parte interesada (cfr. art. 132 , inc. $3^{\circ}$ ).

Vale recordar que el Fiscal de Estado posee "personería" para demandar la nulidad de leyes, decretos, reglamentos o resoluciones contrarios a las prescripciones constitucionales locales en el solo interés de la ley o en la defensa de los intereses fiscales (art. 135, párrafo 3. ${ }^{\circ}$, ibid.).

\section{q) Constitución de la Provincia de Santiago del Estero}

Su art. 194, inc. $10^{\circ}$, ap. ' $b$ ', atribuye al Superior Tribunal de Justicia, en materia judicial, el ejercicio de la jurisdicción originaria y exclusiva en las acciones declarativas de inconstitucionalidad contra leyes, ordenanzas, decretos, reglamentos o resoluciones de carácter general que estatuyan sobre materias de la Constitución local y se controvierta por parte interesada.

\section{r) Constitución de la Provincia de Tierra del Fuego}

En el art. 157 , inc. $10^{\circ}$, se fija la competencia originaria y exclusiva del Superior Tribunal de Justicia para conocer y resolver en las cuestiones que se promuevan en caso concreto y por vía de acción de

nalidad de leyes, decretos, cartas y ordenanzas municipales, acordadas, resoluciones o actos administrativos, e intervenir en las que inicie el Fiscal de Estado de la Provincia. 
inconstitucionalidad de leyes y demás normas jurídicas que estatuyan sobre materias regidas por la Constitución provincial.

Conviene poner de resalto que, cuando el Superior Tribunal de Justicia declare por unanimidad y por tercera vez la inconstitucionalidad de una norma jurídica materia de litigio, podrá resolver la suspensión de su vigencia en pronunciamiento expreso dictado por separado, el que será notificado fehacientemente a la autoridad que la dictara y dado a conocer en el diario de publicaciones legales dentro de los 5 días de emitido (art. 159, ibid.).

Sostiene Sisinni que la instrumentación de la acción de inconstitucionalidad se encuentra prevista en el Capítulo XIII del Código Procesal Civil, Comercial, Laboral, Rural y Minero, entre los arts. 315 a $318^{61}$.

El art. 315 de dicho código regula la procedencia de la acción. El 316 dispone que el accionante, para incoarla, habrá de sufrir afectación en sus intereses y plantear la demanda dentro de los 30 días siguientes a que ello ocurra en virtud de la aplicación de la norma atacada; vencido tal plazo, se extinguirá la competencia originaria del Superior Tribunal, sin perjuicio de que el interesado pueda ocurrir a la jurisdicción ordinaria en defensa de los derechos patrimoniales que considere afectados. Por el art. 317 se especifica a quién deberá correrse traslado de la demanda, según corresponda, estableciéndose que el trámite a imprimir a la acción será el del juicio sumario. Por último, el art. 318 pauta que, si se admitiera el planteo del demandante, el pronunciamiento del Tribunal se atendrá a la declaración de inconstitucionalidad, dejando a salvo la posibilidad de reclamar, por la vía pertinente, las reparaciones correspondientes ${ }^{62}$.

\section{s) Constitución de la Provincia de Tucumán}

Un caso atípico es el de la Provincia de Tucumán, cuya Constitución ha previsto en su art. 133 , párrafo $1 .^{\circ}$, que la obediencia de la Constitución y el equilibrio de los poderes que ella establece, queda-

61 SISINNI, Julio N.: "La acción autónoma de inconstitucionalidad en el ordenamiento normativo fueguino y en la doctrina del Superior Tribunal de Justicia", en el colectivo coordinado por Germán J. BIDART CAMPOS y Andrés GIL DomINGUEZ, El Derecho Constitucional del Siglo XXI, Ediar, Bs. As., Rep. Arg., 2000, pág. 507.

62 Conforme; para todas las referencias al código ritual fueguino, el autor $\checkmark$ el trabajo citados en la nota anterior, págs. 507/508. 
rán especialmente garantizados por un Tribunal Constitucional compuesto de cinco miembros.

En función de lo determinado en el artículo constitucional 134, inc. $12^{\circ}$, dicho Tribunal recepta competencia para declarar la inconstitucionalidad de las leyes, decretos, ordenanzas, con el alcance general previsto en el párrafo final del art. 22 ibid., es decir, la declaración de inconstitucionalidad con efectos generales de derogación de la norma impugnada ${ }^{63}$. Es dable aclarar que el mencionado Tribunal no ha sido implementado $y$, por ende, no se encuentra en funcionamiento.

Cabe recordar que recientemente, a través de la Ley Prov. $n .^{\circ}$ 6.944 (B.O. del 08/03/99), ha entrado en vigor el Código Procesal Constitucional local, en cuyo Título III (denominado "Control jurisdiccional de constitucionalidad"), y específicamente en el Capítulo 2 (intitulado "Por acción»), se reglamenta - inter alia- el ejercicio, contenido, alcances y efectos de la acción declarativa de inconstitucionalidad.

Al respecto, se ha establecido que puede deducirse acción tendente a obtener la declaración de inconstitucionalidad total o parcial de una norma legal o disposición normativa con fuerza de ley, provincial o municipal, o de reglamentos u ordenanzas provinciales o municipales, o actos administrativos, para hacer cesar un estado de incertidumbre sobre la constitucionalidad de una relación jurídica, siempre que dicha falta de certidumbre pueda producir un perjuicio o lesión al actor y éste no dispusiere de otro medio legal para ponerle término inmediatamente (art. 89) ${ }^{64}$.

El procedimiento se encuentra reglado de acuerdo con los siguientes lineamientos, demarcados en el art. 90 ibid.:

- La demanda debe interponerse dentro del plazo de 60 días corridos a contar desde la publicación oficial de la norma cuestionada, la notificación o el conocimiento del acto administrativo. Para el supuesto de que el plazo mencionado caduque, la cuestión constitucional podrá plantearse por vía de

63 Si el Tribunal no hiciere lugar a la declaración de inconstitucionalidad de la norma objetada, la cuestión no podrá ser reeditada, quedando a salvo la posibilidad de que los interesados la impugnen ante los jueces, mas ya con efectos específicos (art. constitucional 22, in fine).

64 Cabe recordar que la acción meramente declarativa de certeza ha sido regulada en el art. 282 del Código Procesal Civil y Comercial local. Para el diseño de dicha institución la mencionada norma provincial se inspiró en el art. 322 del Código Procesal Civil y Comercial de la Nación. 
excepción, si correspondiere de acuerdo con las circunstancias del caso (inc. $1 . \%$ ).

- Si lo cuestionado es una norma o acto administrativo provincial o municipal, debe correrse traslado a la Provincia, a la Municipalidad o al ente autárquico que lo emitió, confiriendo -en todos los casos - intervención al Ministerio Público (inc. $2 .^{\circ}$ ).

- En caso de que la norma o acto cuestionados protejan los intereses de alguna categoría de personas, el tribunal actuante deberá integrar la litis dando intervención a las entidades representativas de las mismas (inc. $3^{\circ}$ ).

- La tramitación se canaliza procesalmente de acuerdo con las disposiciones del proceso sumario previsto en el Código de Procedimientos en lo Civil y Comercial local (inc. $4 .^{\circ}$ ).

- Si la sentencia resuelve que la norma o el acto son inconstitucionales, la disposición así tildada no será aplicable a la actora ni a los representados por ella si ésta fuere una institución intermedia con personería jurídica cuyos estatutos contemplen tal representación (inc. $5^{\circ} \%$.

El art. 90 finaliza dotando a la acción declarativa de inconstitucionalidad de un radio de cobertura muy amplio, pues regla que el caso contencioso que da lugar a esa acción no se limita a las cuestiones de índole económica de interés privado del justiciable, sino que comprende la defensa, por parte de cualquier persona o asociación, de los intereses públicos que se encuentren protegidos explícita o implícitamente por los órdenes jurídicos nacional, provincial o internacional que fueren de aplicación en sede provincial.

\section{Breves acotaciones acerca de la comparación de las normativas constitucionales citadas}

En un bosquejo meramente ilustrativo, a grandes trazos y en coordenadas seleccionadas arbitrariamente, podría decirse que:

a) La mayor parte de las Constituciones provinciales adjudica la jurisdicción originaria y exclusiva en las acciones de inconstitucionalidad al Superior Tribunal de la respectiva jurisdicción local (Corte de Justicia, Suprema Corte de Justicia, Superior Tribunal de Justicia, etc., de acuerdo con la denominación que se adopte). 
En otras (v. gr., las de Buenos Aires, La Pampa, Mendoza, San Luis, Santa Cruz) el texto constitucional refiere a una jurisdicción originaria y una de apelación en cabeza del respectivo órgano judicial supremo en el orden local; lo que implica que dicha jurisdicción no es exclusiva de éste.

Puede visualizarse, además, que para el conocimiento y la resolución en instancia originaria y exclusiva de las acciones declarativas de inconstitucionalidad, las Constituciones de Córdoba y Chubut exigen que sus respectivos Tribunales Superiores de Justicia actúen en pleno.

b) La mayoría de las Constituciones requiere que la constitucionalidad de la ley (en sentido material) sea controvertida por parte interesada; regla de la que pareciera escapar la previsión de la Constitución de la Ciudad Autónoma de Buenos Aires.

Es interesante destacar en torno de la amplitud del interés que debe esgrimir el interesado, que en la Constitución de Río Negro se estipula que la acción podrá ser promovida sin lesión actual.

c) En relación con el objeto de la acción de inconstitucionalidad, hay coincidencia generalizada en cuanto a que pueden censurarse las leyes, decretos, ordenanzas, resoluciones y reglamentos que estatuyan sobre materia regida en las propias Constituciones locales.

Como casos que escapan de los lineamientos genéricos, podría ubicarse a las Constituciones de Córdoba y Chubut, que incluyen como materia potencialmente objeto de control a las cartas orgánicas. También, y por su marcada amplitud, a las de Río Negro, que alude genéricamente a "normas"; Tierra del Fuego, que apunta a "leyes y demás normas jurídicas»; y de la Ciudad Autónoma de Buenos Aires, que incluye -además de las leyes y decretos - a ucualquier norma de carácter general emanada de las autoridades de la Ciudad". A su turno, la de La Pampa hace también extensiva su previsión a los edictos.

Existe, asimismo, coincidencia en cuanto a que la normativa censurable debe estatuir materia regida en la Constitución provincial. De ello escapa la Constitución porteña, que involucra no sólo a la normativa contraria a ella sino a la que se encuentra en pugna con la Constitución Nacional.

d) Una particularidad de la Constitución sanjuanina estriba en que la jurisdicción originaria y exclusiva de la Corte de Justicia local puede quedar únicamente excitada por los planteos de inconstitucio- 
nalidad que le formulen (por vía de acción) ciertos funcionarios, entre los que se cuenta el Fiscal de Estado y el Fiscal General de la Corte.

Por su parte, acuerdan expresamente legitimación o "personería" (mas no en forma exclusiva) al Fiscal de Estado, las Constituciones de Chaco, Chubut, Jujuy, La Pampa, La Rioja, Mendoza, Misiones, Salta, San Luis y Santa Cruz.

e) En punto a los efectos de la declaración de inconstitucionalidad, es dable citar los casos de las Constituciones de la Ciudad de Buenos Aires y de Tucumán, que pautan efectos abrogatorios de la norma en cuestión, salvo que (en el marco porteño) se tratara de una ley y la Legislatura la ratifique, por mayoria de los dos tercios de los miembros presentes, dentro de los 3 meses de la sentencia declarativa. A su turno, y respecto de la normativa tucumana, justo es remarcar que la previsión comentada queda prisionera de la cárcel de la teoría, ya que pervive en la Constitución formal mas carece de aplicación práctica en la Constitución material, pues el Tribunal Constitucional que ha concebido desde el plano normológico, no ha sido instituido $y$, por ende, no ha entrado en funcionamiento, $v$ todo hace presagiar que tampoco funcionará, al menos, en un futuro próximo.

Por su parte, si el pronunciamiento fuere desestimatorio de la acción, en el caso de a normativa tucumana se dispone que la cuestión no podrá ser reeditada, quedando a salvo la posibilidad de que los interesados la impugnen ante los jueces, mas ya con efectos específicos.

A su turno, la Constitución de la Ciudad Autónoma de Buenos Aires prevé que la ratificación que la Legislatura haga de la ley reputada inconstitucional no altera los efectos que para el caso concreto produce dicha declaración ni obtura el posterior control difuso de constitucionalidad a cargo de todos los jueces y del propio Tribunal Superior.

Algunas previsiones que merecen ser tomadas en consideración son, por ejemplo, las de las Constituciones de Chaco, que prevé que la inconstitucionalidad declarada por el mencionado Tribunal produce la caducidad de la ley, decreto, ordenanza o disposición en la parte afectada por aquella declaración; de Chubut, que establece que, cuando el Superior Tribunal declara por dos veces consecutivas o tres alternadas la inconstitucionalidad de una norma legal, ésta pierde vigencia a partir del día siguiente a la publicación oficial de la sentencia definitiva; de Neuquén, que contiene una previsión similar a la chaqueña; de Río Negro, que estipula que cuando el Superior Tribunal de 
Justicia declara por unanimidad y por tercera vez la inconstitucionalidad de un precepto materia de litigio contenido en una norma provincial o municipal puede, en resolución expresa dictada por separado, declarar abrogada la vigencia de aquella norma (hipótesis análoga a la de la Constitución de Tierra del Fuego que, sin embargo y a diferencia de aquélla, no dispone la abrogación sino la suspensión de la vigencia del precepto) o, si se trata de una ley, el Tribunal debe dirigirse a la Legislatura para que elimine su oposición a la Ley Fundamental y si no lo hiciere en el plazo de 6 meses de recibida la comunicación del órgano judicial, éste ordena la publicación del fallo y se produce la derogación automática de la norma tachada de inconstitucional; de San Juan, que pauta que la inconstitucionalidad declarada por la Corte de Justicia debe ser comunicada formal y fehacientemente a los poderes públicos correspondientes, a los fines de sus modificaciones y adaptaciones al orden jurídico vigente; o, por último, la de San Luis, que diseña una prescripción de similar calibre a la sanjuanina.

\section{EPÍLOGO}

Luego del repaso de las normativas respectivas insertas en las Constituciones provinciales referenciadas, y para concluir el presente trabajo, pasamos a brindar ciertas ideas finales que la cuestión en tratamiento nos sugiere:

1. No concebimos la existencia de confusión ontológica posible entre la acción declarativa de inconstitucionalidad y la acción meramente declarativa.

2. La acción declarativa de inconstitucionalidad desborda claramente el perímetro de la descripción procesal de la figura de la acción meramente declarativa prevista concretada en el art. 322 del C.P.C.C.N., mas el acogimiento de aquélla, aun discurriendo por la senda de la mere declarativa y, como afirma Bidart Campos, rinde resultados positivos para brindar curso procesal a cuestiones constitucionales y aplicabilidad judicial a la fuerza normativa de la Constitución ${ }^{65}$.

3. Seria conveniente debatir acerca de si es posible, a través de la acción declarativa de inconstitucionalidad, que la pretensión tenga

65 BIDART CAMPOS, Germán J.: EI Derecho de la Constitución y su fuerza normativa, Ediar, Bs. As., Rep. Arg., 1995, pág. 316. 
por objeto obtener una declaración judicial de anticonstitucionalidad por omisión ${ }^{66}$ y no exclusivamente por acción.

Respecto del control de las omisiones inconstitucionales, sería razonable capitalizar las experiencias del derecho comparado de otros países y el derecho público provincial vernáculo, así como también tomar en consideración algunos precedentes que la propia Corte ha ido elaborando en su derrotero jurisprudencial.

En relación con el derecho comparado (ya desde las normativas constitucional o infraconstitucional, ya desde la doctrina judicial), permítasenos señalar que, además de los conocidos casos de -inter alia- la ex Yugoslavia ${ }^{67}$; Portugal ${ }^{68}$; Alemania, Austria, España e Italia69; Brasil70; Colombia71; Costa Rica ${ }^{72}$; Ecuador ${ }^{73}$; Paraguay74; Vene-

66 Ver, BAZÁN, Víctor, por ejemplo en: «Un sendero que merece ser transitado: el control de la inconstitucionalidad omisivan, en el libro colectivo coordinado por el mismo autor: Desafíos del control de constitucionalidad, Ediciones Ciudad Argentina, Bs. As., Rep. Arg., 1996, págs. 171/269; "La Constitución y la jurisprudencia contra la inercia legislativa o el principio del fin de las excusas", en Economia, Constitución y derechos sociales, volumen múltiple coordinado por Germán J. BiDART CAMpos, Ediar, Bs. As., Rep. Arg., 1997, págs. 111/174.

67 Art. 377 de la Constitución de la -desaparecida-República Socialista Federativa de Yugoslavia (27 de febrero de 1974).

68 Art. 283 de la Constitución portuguesa y art. 68 de la Ley del Tribunal Constitucional.

69 En los casos de Alemania, Austria, España e Italia, si bien no existen expresas disposiciones constitucionales al respecto, ha sido importante el despliegue de las correspondientes jurisdicciones constitucionales para controlar las omisiones legislativas relativas, v.gr., y en función de las respectivas particularidades de cada uno de los sistemas de esos países, es dable verificar - como se ha enseñado- la utilización de remedios unilaterales, que suponen la reparación inmediata de la omisión por la propia sentencia del Tribunal Constitucional, por caso, las "sentencias interpretativas " $y$, dentro de éstas, las "manipulativas" y, más especificamente, las "aditivas"; y de remedios bilaterales, que suponen la necesidad de colaboración entre el Tribunal Constitucional $y$ el legislador $-y$, en ocasiones, también del juez ordinario, en cuyo caso, pasarían a ser multilaterales-, por ejemplo, las declaraciones de mera incompatibilidad o de inconstitucionalidad sin nulidad, las "sentencias de apelación", las que declaran que la ley "todavía no es inconstitucional», el retraso de los efectos de la sentencia para dar tiempo a la intervención del legislador y las "sentencias aditivas de principio" o las "sentencias delegación») [cfr. Díaz Revorio, Francisco J.: "El control de constitucionalidad de las omisiones legislativas relativas en el derecho comparado europeo", Revista Española de Derecho Constitucional, n. ${ }^{\circ} 61$, Año 21, enero-abril 2001, Centro de Estudios Políticos y Constitucionales, Madrid, España, págs. 85/86].

70 Existen disposiciones relativas al control de las omisiones inconstitucionales, tanto en la Constitución Federal de 1988 (art. 103, $\S 2 .{ }^{\circ}$ ), cuanto en las de 
zuela ${ }^{75} y$, ya en el contexto argentino, de las Constituciones de las Pro-

algunos de sus Estados, v.gr., de Río Grande do Sul (art. 95, inc. XII, letra «d»); de

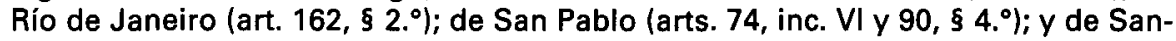
ta Catarina (art. 85, $\$ 3 .{ }^{\circ}$ \%.

71 Pueden computarse algunas interesantes causas resueltas por la Corte Constitucional de ese país acerca de las «omisiones legislativas»; por caso, las Sentencias $\mathrm{n} .^{\circ} \mathrm{C}-543 / 96, \mathrm{C}-080 / 99, \mathrm{C}-843 / 99$, C-867/99, C-956/99, C-1.433/2000, C007/2001, C-1.064/2001.

72 Por medio de la Reforma Constitucional 7.128, de 18/08/89 (Gaceta 166, de 01/09/89) se crea la Jurisdicción Constitucional en Costa Rica, incluyéndose en el art. 10 de la Constitución de 1949 que «corresponderá a una Sala especializada de la Corte Suprema de Justicia declarar, por mayoría absoluta de sus miembros, la inconstitucionalidad de las normas de cualquier naturaleza y de los actos sujetos al Derecho Público". Asimismo, se reformaron los artículos constitucionales 48 , 105 y 128.

El aspecto de la reforma constitucional de 1989 mencionado en primer término (jurisdicción constitucional), fue desarrollado por la Ley $n .^{\circ} 7.135$ (de 11/10/89). Por imperio del art. 4 de tal ley se dispone - en cuanto a lo que aquí interesa - que «la jurisdicción constitucional se ejerce por la Sala Constitucional de la Corte Suprema de Justicia establecida en el artículo 10 de la Constitución Polítican.

Específicamente, el art. 73 de la mencionada Ley determina los casos en que corresponde la articulación de la acción de inconstitucionalidad, incluyendo - ya en relación con el control de las omisiones inconstitucionales - los siguientes:

«a) Contra las leyes $y$ otras disposiciones generales, incluso las originadas en actos de sujetos privados, que infrinjan, por acción u omisión, ałguna norma o principio constitucional.

"b) Contra los actos subjetivos de las autoridades públicas, cuando infrinjan, por acción $u$ omisión, alguna norma o principio constitucional, si no fueren susceptibles de los recursos de hábeas corpus o de amparo. (...)

"f) Contra la inercia, las omisiones y las abstenciones de las autoridades públicas" -en todos los casos el subrayado nos corresponde-.

73 El art. 18, párrafo $1^{\circ}$, de la Constitución ecuatoriana (1998) expresa: "Los derechos y garantías determinados en esta Constitución y en los instrumentos internacionales vigentes, serán directa e inmediatamente aplicables por y ante cualquier juez, tribunal o autoridad" -el remarcado debe atribuírsenos-.

74 En una fórmula dispositiva generosa y bajo el siguiente rótulo: «De los derechos y garantias no enunciados", el art. 45 de la Constitución del Paraguay (1992) reza: "La enunciación de los derechos y garantías contenidos en esta Constitución no debe entenderse como negación de otros que, siendo inherentes a la personalidad humana, no figuren expresamente en ella. La falta de ley reglamentaria no podrá ser invocada para negar ni para menoscabar algún derecho o garantían -sobremarcado propio-.

La parte in fine de dicho precepto excede, a nuestro criterio, el mero ámbito de los derechos y garantías "no enunciados», institucionalizando una vocación de operatividad (que en este contexto debe ser entendida como alegabilidad directa ante los tribunales) que involucra también a los explícitos.

75 Por imperio del art. 336 de la Constitución de la República Bolivariana de Venezuela (1999) se atribuyó a la Sala Constitucional del Tribunal Supremo de 
vincias de Río Negro ${ }^{76}$ y Tucumán ${ }^{77}$ - entre otras ${ }^{78}$ - puede computarse -ejemplificativamente - un interesante precedente jurisdiccional en República Dominicana (del 24/02/99) por el cual la Suprema Corte de Justicia declaró que el recurso de amparo previsto en el art. 25.1 de la Convención Americana sobre Derechos Humanos ues una institución del derecho positivo dominicano", por haber sido aquella Convención adoptada y aprobada por el Congreso el 25/12/77, en los términos del art. 3 de la Constitución de ese país; además, y ante la ausencia de norma procedimental relativa a dicho "recurso», se entregó a delinear los trazos al que debe sujetarse el procedimiento en el que discurra el amparo (competencia, plazo para interponerlo, audiencia para su conocimiento, parámetro temporal al que debe ajustarse el juez al dictar sentencia, costas, etcétera) -cfr., respectivamente, puntos dispositivos primero y segundo de la aludida resolución-.

Ya en cuanto a los antecedentes jurisprudenciales de la Corte, vale incluir en la nómina - entre otras - a la causa «Ekmekdjian c/

Justicia competencia - inter alia- para: "Declarar la inconstitucionalidad del poder legislativo municipal, estatal o nacional, cuando hayan dejado de dictar normas o medidas indispensables para garantizar el cumplimiento de la Constitución, o las hayan dictado en forma incompleta, y establecer el plazo y, de ser necesario, los lineamientos de su corrección" (inc. $7 .^{\circ}$ ) -énfasis propio-.

76 Concretamente, en el artículo constitucional provincial 207, inc. $2 .^{\circ}$, ap. 'd'.

Sobre el tema, ver BAZAN, Víctor: "Hacia la plena exigibilidad de los preceptos constitucionales: el control de las omisiones inconstitucionales. Especial referencia a los casos de Brasil y Argentinan, en el libro colectivo coordinado por el mismo autor: Inconstitucionalidad por omisión, Temis, Bogotá, Colombia, 1997, págs. $41 / 108$, en esp. págs. $76 / 83$.

77 En el art. 134, inc. $22^{\circ}$, de la Constitución local se acuerda al Tribunal Constitucional (que aún no está en funcionamiento) la atribución de «entender en la acción que deduzca el Poder Ejecutivo contra el Poder Legislativo, o un Departamento Ejecutivo contra el Concejo Deliberante, por demora en pronunciarse sobre proyectos de leyes u ordenanzas que aquéllos hubieren presentado. El Tribunal, apreciando las circunstancias, fijará un plazo para que se expidan, vencido el cual sin que ello se hubiera producido, podrá autorizar al accionante para la directa promulgación, total o parcial, de la norma de que se trataren.

78 Nos referimos a los casos de las Constituciones de la Ciudad Autónoma de Buenos Aires (art. 10), de la Provincia de Río Negro (art. 14), de la Provincia de Chubut (art. 21) y de la Provincia de Salta (art. 16).

En torno al tema, específicamente en punto al art. 10 de la Constitución de la Ciudad Autónoma de Buenos Aires y tangencialmente respecto de las restantes Constituciones, ver BAZAN, VICTOR: "La operatividad de los derechos y las garantías no obstante las omisiones o insuficiencias reglamentarias inconstitucionales", en el libro colectivo coordinado por BidArT CAMPos, Germán, y GIL Dominguez, Andrés: Instituciones de la Ciudad Autónoma de Buenos Aires, La Ley, Bs. As., Rep. Arg., 2001, págs. 97/128. 
Sofovich" (del 07/07/92) y, con anterioridad a ella, al siguiente conjunto de casos resuelto por conjueces: "Bonorino Peró», "Perugini", "Durañona y Vedia" y "Grieben» 79 .

4. No es imprescindible el dictado de una ley especial para el funcionamiento de la acción declarativa de inconstitucionalidad, 20 acaso hubo necesidad de ella para concebir pretorianamente a la de amparo, insertándola en el contexto garantista (casos "Siri» 80 y "Kot»" ${ }^{81}$ )?; ¿0 tal vez la hubo para permitir la declaración de inconstitucionalidad de la norma en que se funden el acto o la omisión lesivos al resolver las acciones de amparo, años antes de que se plasmara la reforma constitucional de 1994 (caso "Peralta") ${ }^{82}$ y aun a despecho de una expresa norma legal en contrario (art. 2, inc. 'd' parte final, de la Ley Nac. $\left.n .^{\circ} 16.986\right)$ ?

5. En éste como en tantos otros aspectos, sería muy útil aprovechar la experiencia (tanto normativa cuanto jurisprudencial) del derecho público provincial en torno a las acciones declarativas de inconstitucionalidad ${ }^{83}$.

6. Se ha sostenido acertadamente que los beneficios que la pretensión declarativa trae aparejados para el control de constitucionalidad, no serían completos si quien la deduce no cuenta a su favor con la posibilidad de obtener, en el curso del proceso, medidas cautela-

79 De ese conjunto de fallos, el recaído en "Bonorino Peró" el 15/11/85 (Jurisprudencia Argentina, t. 1986-I, Bs. As., Rep. Arg., págs. 95 y ss.), inauguró el camino seguido luego por los restantes y concretó un control de constitucionalidad con sentido institucional de una omisión inconstitucional, la de mantener «actualizada con significación económica la remuneración de los jueces, cuando un deterioro significativo trasuntaba en esa omisión una violación a la garantía de intangibilidad impuesta por el [ex] art. 96 [hoy 110] de la Constitución», dando operatividad a la mencionada garantía (BIDART CAMPOS, Germán J.: La interpretación y el control constitucionales en la jurisdicción constitucional, Ediar, Bs. As., Rep. Arg., 1987, pág. 100).

80 Fallos, 239: 459.

81 Fallos, 241: 291.

82 Sin perjuicio de despejarse toda duda a partir del caso "Peralta" en relación con la atribución de ejercer control de constitucionalidad en el amparo, no pueden soslayarse señeros precedentes previos en los que se esbozó dicha posibilidad, v. gr., "Outon, Carlos J. y otros" (Fallos, 267: 215).

${ }_{83}$ Ya respecto de los diversos modelos de acciones de inconstitucionalidad en el plano del derecho comparado más allá de las fronteras nacionales, ver TORICELLI, Maximiliano: "La perspectiva de la acción declarativa en el Siglo XXI", en el volumen colectivo citado en nota 61 , págs. $495 / 498$. 
res ${ }^{84}$; por esa razón, e importante que la Corte acompase la evolución de la acción declarativa de inconstitucionalidad con un criterio despojado de formalismcs excesivos a la hora de meritar la admisión de la petición cautelar, de modo tal que el derecho que se invoca para sustentar la acción $-y$ que motiva la petición de declaración de invalidez constitucional de la nurma que lo turba-, no quede desguarnecido ni se torne ilusorio comú consecuencia de la duración del proceso.

7. Los derechos de incidencia colectiva (según la terminología del art. 43 , párrafo $2 .^{\circ}$, de la C.N.) receptan adecuado cauce de tutela en la acción declarati ya de inconstitucionalidad, además de ser ejercitables a través de lé acción de amparo, razonamiento que la Corte complementa con un t:aludable ensanchamiento perceptivo de la legitimación procesal parił la articulación de las mismas.

8. Ambos proiesos, acciones de amparo y declarativa de inconstitucionalidad, importan eslabones muy importantes que, a manera de cuña, han hendido el criterio otrora impenetrablemente reacio de la Corte en orden a admitir el control de constitucionalidad por vía de acción.

9. El análisis disl devenir jurisprudencial de la C.S.J.N. denota, según Rosales Cuello que los casos "Provincia de Santiago del Estero c/ Y.P.F." y "Lorenzo", proporcionaron a la acción declarativa el marco «sustancial»; mientías que el caso "Gomer" le brindó el marco "procesal»85.

Por su parte, y como afirma Bianchi86, si bien la Corte nunca ha abandonado (formalmente) el holding de "Gomer", que exige la presencia de los requisitcis de la acción meramente declarativa de certeza, en la práctica puediın detectarse numerosos casos en los cuales ha admitido acciones declarativas de inconstitucionalidad donde la única y eventual incertid u mbre consistía en determinar si la norma cuestionada era inconstitu!;ional o no87.

84 Rosales Cuello Ramiro: «Acción declarativa y control constitucional. Estado actual de la cuestion en la doctrina de la Corte Suprema de Justicia de la Nación", Jurisprudencia Argentina, suplemento especial, 06/12/2000, Bs. As., Rep. Arg., pág. 16.

85 Ibidem, pág. 10 ,

86 BIANCHI, Albertc B.: op. cit. ["De la acción declarativa de certeza...»], pág. 5.

87 Es lo que sucedió, a nuestro juicio (y por enunciar un ejemplo relativamente reciente) en la cau :a "Nación Administradora de Fondos de Jubilaciones y Pensiones S.A. c/ Provincia de Catamarcan (Fallos, 323: 1206), resuelta el 
El caso "Fayt" desnudó un innovador criterio de la Corte, pudiendo ser visualizado como un antecedente válido para ponderar la trascendencia funcional prospectiva de la acción declarativa, y meritarla potencialmente útil para lograr no ya sólo la inconstitucionalidad de una norma subconstitucional, sino, además, para esterilizar un precepto constitucional.

Sin embargo, la Corte tampoco ha resignado la exigencia de que converja caso contencioso (art. 2 de la Ley Nac. $n .^{\circ} 27$ ), en el que se persiga en concreto la determinación del derecho entre partes adversas, sosteniendo que no existe "causa" cuando se procura la declaración general y directa de inconstitucionalidad de las normas o actos de otros poderes 8 .

10. Si en el trayecto procesal de la acción meramente declarativa el juez se encontrara con el obstáculo de una norma que considera contraria a la Constitución, debe removerla, aun sin pedido de parte, declarando su inconstitucionalidad e inaplicándola en el caso concreto, con lo cual despejará el camino dejándolo expedito para el dictado de la sentencia que admita la acción mere declarativa incoada.

$16 / 05 / 2000$, en la que, bajo un alegado estado de incerteza, la actora procuraba (y logró) que la Corte declarara la inconstitucionalidad de la Resolución $n .^{\circ}$ 9/97 de la Ad́ministración General de Rentas y Registro Territorial de la Provincia de Catamarca, en cuanto pretendía incluir en la base de cálculo del impuesto a los ingresos brutos a la parte de la comisión prevista en el art. 116, párrafo $2 .^{\circ}$, de la Ley Nac. $n .^{\circ} 24.241$ (destinada al pago de la prima del seguro colectivol, lo que, en definitiva, lesiona el principio de supremacía legal del art. 31 de la C.N.

88 Ver, por ejemplo, lo resuelto recientemente (20/04/99) in re "Drogueria Aries S.A. c/.Provincia de Santa Fe y otros" (La Ley, t. 1999-D, Bs. As., Rep. Arg., págs. 514 y ss.) y la referencia respecto de la necesaria configuración de "caso" o "causa" que el considerando $5 .^{\circ}$ formula, reenviando sobre el punto a Fallos, 12: 372; 24: 248; 95: 290; 107: 179; 115: 163; 156: 318; 243: 176 -entre otros-1.

En idéntico sentido, unos días antes de emitir el resolutorio en «Droguería Aries", la Corte requirió (el 31/03/99) análogo tenor de exigencia en "Gómez Diez, Ricardo y otros c/ Congreso de la Nación" (Fallos, 322: 528), poniendo de manifiesto la conveniencia de utilizar con sinonimia los términos "causas", "casos" o "asuntos" y, por último, expidiéndose por la falta de legitimación de los actores, tres diputados nacionales por la Provincia de Salta que, invocando sus respectivos caracteres de ciudadanos y representantes de su provincia, articularon acción declarativa de certeza e inconstitucionalidad contra el P.E.N. y el Congreso de la Nación - Cámara de Senadores - con el objeto de obtener la sanción de una nueva ley convenio de coparticipación impositiva. Naturalmente, y sobre la base del criterio anunciado, declaró improcedente el recurso extraordinario planteado. 
Reiteramos aquí lo que dijimos hasta el cansancio: la tesis que postula la proscripción de declarar de oficio la inconstitucionalidad de las normas aparece destituida de fundamento jurídico, ya que la supremacía constitucional es de orden público y el requerimiento de las partes no puede funcionar como elemento determinante de la actividad jurisdiccional cuando de desechar normas refractarias a la Constitución se trate. Afortunadamente, pareciera que la C.S.J.N. abandona (al menos en una reciente mayoría) paulatinamente tal prejuiciosa posición de autoproscribirse ejercer el control de constitucionalidad ex officio 89 .

11. Sería deseable, también, en dicho contexto, que la Corte eludiera la tendencia a concretar autodetracciones injustificadas a la tarea de control de constitucionalidad en cabeza del poder judiciario, v.gr., a través de la doctrina de las political questions, en torno de las cuales un paso adelante se diera in re "Fayt", mas poco tiempo después, lamentablemente, se desandara el camino en «Guadalupe Hernández", con lo que el Tribunal continúa evidenciando una actitud intercadente al respecto.

89 Los doctores Fayt y Belluscio, jueces de la Corte, han asumido desde hace bastante tiempo (aproximadamente en 1984) la posición contraria al criterio negatorio mayoritario de la Corte. A ellos se unió luego Boggiano, alrededor de 1998.

Valga aclarar que en un interesante y reciente caso (“Mill de Pereyra, Rita Aurora y otros c/ Provincia de Corrientes", del 27/09/2001), la Corte ha comenzado - al menos con el aval de la mayoría de sus componentes - a mudar su posición proscriptiva del control de constitucionalidad de oficio. Así, y además de los mencionados FAYT, BELLUSCIO y BOGgIANo, se han acoplado explícitamente VAZOUEZ, e implícitamente, LOPEZ Y BOSSERT. Por la senda contraria, mantienen su posición contraria Nazareno, Petracchi y Moliné O'Connor.

El pronunciamiento citado puede consultarse en La Ley (Suplemento de Derecho Constitucionah), del 30/11/2001, Bs. As., Rep. Arg., págs. 16/36. 